Article

\title{
Deserted Medieval Village Reconstruction Using Applied Geosciences
}

Alexandru Hegyi ${ }^{1,2, *}$, Apostolos Sarris ${ }^{1}$, Florin Curta ${ }^{3}$, Cristian Floca ${ }^{4}$, Sorin Fortiu ${ }^{5}$, Petru Urdea ${ }^{2,6}$, Alexandru Onaca ${ }^{2,6}{ }^{\oplus}$, Fabian Timofte ${ }^{2,6}{ }^{\circ}$, Michał Pisz $^{7}{ }^{\circ}$, Sergiu Timuț ${ }^{8}$, Mădălina Nica ${ }^{8}$, Daiana Maciulschi ${ }^{8}$ and Andrei Stavilă ${ }^{9}$

1 Department of History and Archaeology, Archaeological Research Unit, "Sylvia Ioannou" Chair in Digital Humanities, University of Cyprus, P.O. Box 20537, 1678 Nicosia, Cyprus; sarris.apostolos@ucy.ac.cy

2 Applied Geomorphology and Interdisciplinary Research Centre (CGACI), Department of Geography, West University of Timișoara, 300223 Timiș, Romania; petru.urdea@e-uvt.ro (P.U.); alexandru.onaca@e-uvt.ro (A.O.); fabian.timofte@e-uvt.ro (F.T.)

3 Department of History, University of Florida, Gainesville, FL P.O. Box 117320, USA; fcurta@ufl.edu

4 Doctoral School of Humanities, Field of Historical Studies, Archaeology, West University of Timişoara, 300223 Timis, Romania; cfloca87@gmail.com

5 ArheoVest Association, Timișoara, 300454 Timiș, Romania; sorinfortiu@gmail.com

6 Department of Geography, Faculty of Chemistry, Biology and Geography, West University of Timisoara, 300223 Timis, Romania

7 Institute of Hydrogeology and Geological Engineering, Faculty of Geology, University of Warsaw, 00-927 Warsaw, Poland; michal.pisz@uw.edu.pl

8 Faculty of Architecture and City Planning, Department of Architecture, Polytechnic University of Timisoara, 300006 Timiș, Romania; sergiu.timut@gmail.com (S.T.); madalina.nica95@gmail.com (M.N.); dmaciulschi@gmail.com (D.M.)

9 Department of Romanian Studies, Faculty of Letters, History and Theology, West University of Timişoara, 300223 Timis, Romania; andrei.stavila@e-uvt.ro

* Correspondence: alexandru.hegyi@ucy.ac.cy

Received: 1 June 2020; Accepted: 17 June 2020; Published: 19 June 2020

\begin{abstract}
This study presents a new way to reconstruct the extent of medieval archaeological sites by using approaches from the field of geoinformatics. Hence, we propose a combined use of non-invasive methodologies which are used for the first time to study a medieval village in Romania. The focus here will be on ground-based and satellite remote-sensing techniques. The method relies on computing vegetation indices (proxies), which have been utilized for archaeological site detection in order to detect the layout of a deserted medieval town located in southwestern Romania. The data were produced by a group of small satellites (3U CubeSats) dispatched by Planet Labs which delivered high-resolution images of the Earth's surface. The globe is encompassed by more than 150 satellites (dimensions: $10 \times 10 \times 30 \mathrm{~cm}$ ) which catch different images for the same area at moderately short intervals at a spatial resolution of 3-4 m. The four-band Planet Scope satellite images were employed to calculate a number of vegetation indices such as NDVI (Normalized Difference Vegetation Index), DVI (Difference Vegetation Index), SR (Simple Vegetation Ratio) and others. For better precision, structure from motion (SfM) techniques were applied to generate a high-resolution orthomosaic and a digital surface model in which the boundaries of the medieval village of "Șanțul Turcilor" in Mașloc, Romania, can be plainly observed. Additionally, this study contrasts the outcomes with a geophysical survey that was attempted inside the central part of the medieval settlement. The technical results of this study also provide strong evidence from an historical point of view: the first documented case of village systematization during the medieval period within Eastern Europe (particularly Romania) found through geoscientific methods.
\end{abstract}


Keywords: applied geoscience; satellite remote sensing; Planet Scope images; geophysics; structure from motion; systematization; medieval village reconstruction

\section{Introduction}

Vegetation indices for site identification have been used in archaeology for a long time [1-3]. The most common technique is based on identifying vegetation growth change rates related to the existence of underground structures [2]. Crop marks have been the key component of most aerial archaeology [4-8]. The theory behind studying crop marks is associated with the composition and moisture within the soils [9].

Pits, ditches, or any other "negative" features (namely topographic depressions) are typically filled with organic material which makes the soil more fertile. Moreover, there is commonly a higher moisture content present when compared to their surroundings. As a consequence, the vegetation is usually more abundant on top of such features than in their vicinity. Conversely, architectural features such as walls, foundations, or roads cause soil reduction and are therefore not favourable to plant growth [10].

In a parallel way, crop marks are directly influenced by chemical alterations of the soil composition, which most often indicates intensive human habitation in the area. For example, human activity results in a greater addition of phosphorus or organic materials to the soil [11], which in turn enhances plant growth [12]. Discontinuity and variation in crop or vegetation patterns may therefore be used as a proxy for site identification. Variation of crops can be manifested either in colour or height, particularly during the growing season [2].

Satellite images and unmanned aerial vehicle systems, which are now widely used in archaeology, have allowed many methods of vegetation analysis to be implemented [13] including crop mark analysis [1,7], landscape classification for predictive modeling [14,15], locating paleo rivers and environmental features [3], and many others uses. A great number of studies have been published over the last few decades totalling more than 150 indices for interpreting vegetation/crop marks [2]. Similarly, aerial prospection methods have been used in archaeology for over a century [16,17]. One of the first successful aerial reconnaissance surveys took place in 1913-14 at the excavations of Sir Henry Wellcome in Jebel Moya, Sudan [18]. Special kite systems and helium balloons were popular platforms for carrying remotely operated cameras [19]. The most recent and still ongoing revolution in aerial archaeology is the appearance of remotely piloted unmanned aerial vehicles (UAV) which have evolved into multirotor platforms [20,21]. Aerial imagery has been used for 3D photogrammetry purposes for more than a decade [22] and archaeologists have found a number of ways to explore its potential to obtain high-quality spatial data [23].

This paper applies some of the above techniques to a specified site in southwestern Romania, building on previous research done using geophysical survey techniques that targeted the remains of a deserted medieval village [24]. The coarse resolution of the available data sometimes restricts the research that can be done when multiple satellite images for vegetation analysis are applied to restricted areas. Nonetheless, Planet Labs recently released an entire group of small satellites (3U CubeSats) capable of delivering high-resolution images of the surface of the Earth. More than 150 satellites (dimensions: $10 \times 10 \times 30 \mathrm{~cm}$ ) cover the entire globe obtaining different images of the same given area are obtained at different, relatively short intervals (a few times within one and the same day) at a spatial resolution of between 3 and $4 \mathrm{~m}$.

In addition, aerial images were obtained by means of a Phantom 4 (12.4 Megapixel sensor with FOV $94^{\circ} 20 \mathrm{~mm}$ (35 $213 \mathrm{~mm}$ format equivalent) f/2.8 lens) drone to create a high-resolution digital elevation model, as well as an orthophotomosaic through SfM (structure from motion). All the data obtained by such means have been linked to the results of the geophysical survey in order to explain the distribution of crop marks within the archaeological site. The geophysical survey was carried 
out inside the central part of the medieval settlement. Six hectares were investigated using total field magnetometry, allowing the distribution of houses and dwellings within the site to be depicted. Electrical resistivity tomography and ground penetrating radar highlighted the existence of another ditch around the fortified structure located in the centre of the village [24]. The magnetic map from Mașloc "Șanțul Turcilor" was also used for creating an object-based segmentation and classification algorithm for analysing magnetic anomalies [25].

The main goals of analysing the data in this study are as follows: (1) to show the full extent of the medieval Machalaka oppidum; (2) to demonstrate that Planet Labs satellite constellation constitutes a reliable tool for archaeological research; (3) to prove that this methodology has proven useful for the identification, evaluation and reconstruction of archaeological sites.

The workflow for reconstructing the topography of the medieval village is described in Figure 1.

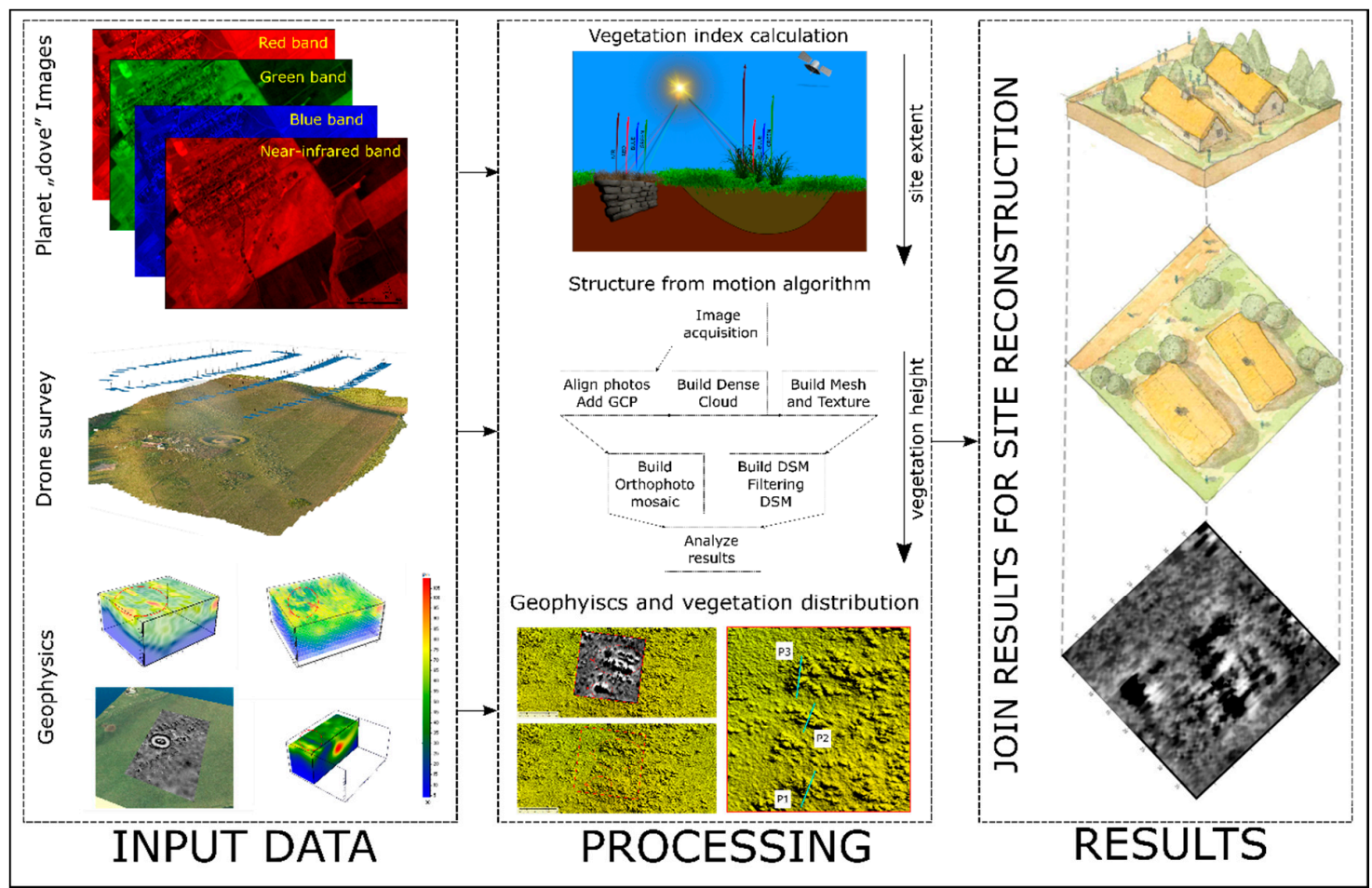

Figure 1. The workflow used to reconstruct the medieval village of Mașloc "Șanțul Turcilor".

\section{Study Area}

The medieval village located at "Șanțul Turcilor" (Figure 2), near the village of Mașloc (Timis, County, Romania) is one of the best-preserved archaeological sites in southwest Romania. It was introduced to the international archaeological literature only in the past few years [24]. From a geographical point of view, the "Șanțul Turcilor" site is located in the southeast of the Vinga Plain, in the vicinity of the western extremity of the Lipovei Hills; this is the contact zone between the Pannonian Basin and the Western Carpathian Mountains in Romania. The landscape is dominated by extensive piedmont plateaus and the flow of the Mures River, fragmented by several autochthonous valleys (like Beregsău) and small tributaries.

The first interpretation of the site was based primarily on the geophysical survey. These results suggested that Mașloc "Șanțul Turcilor" may be one of the first examples of a nucleated village of the medieval period known from southwestern Romania. The site consists of a fortified manor or church and two rows of farmsteads aligned along a street running from southwest to northeast. The fortification has two noteworthy ramparts and two ditches. The settlement surrounds the fortification and it is 
estimated to cover an area of about 12 ha, including the most noteworthy elevations of the piedmont interfluve where the site is situated [24].

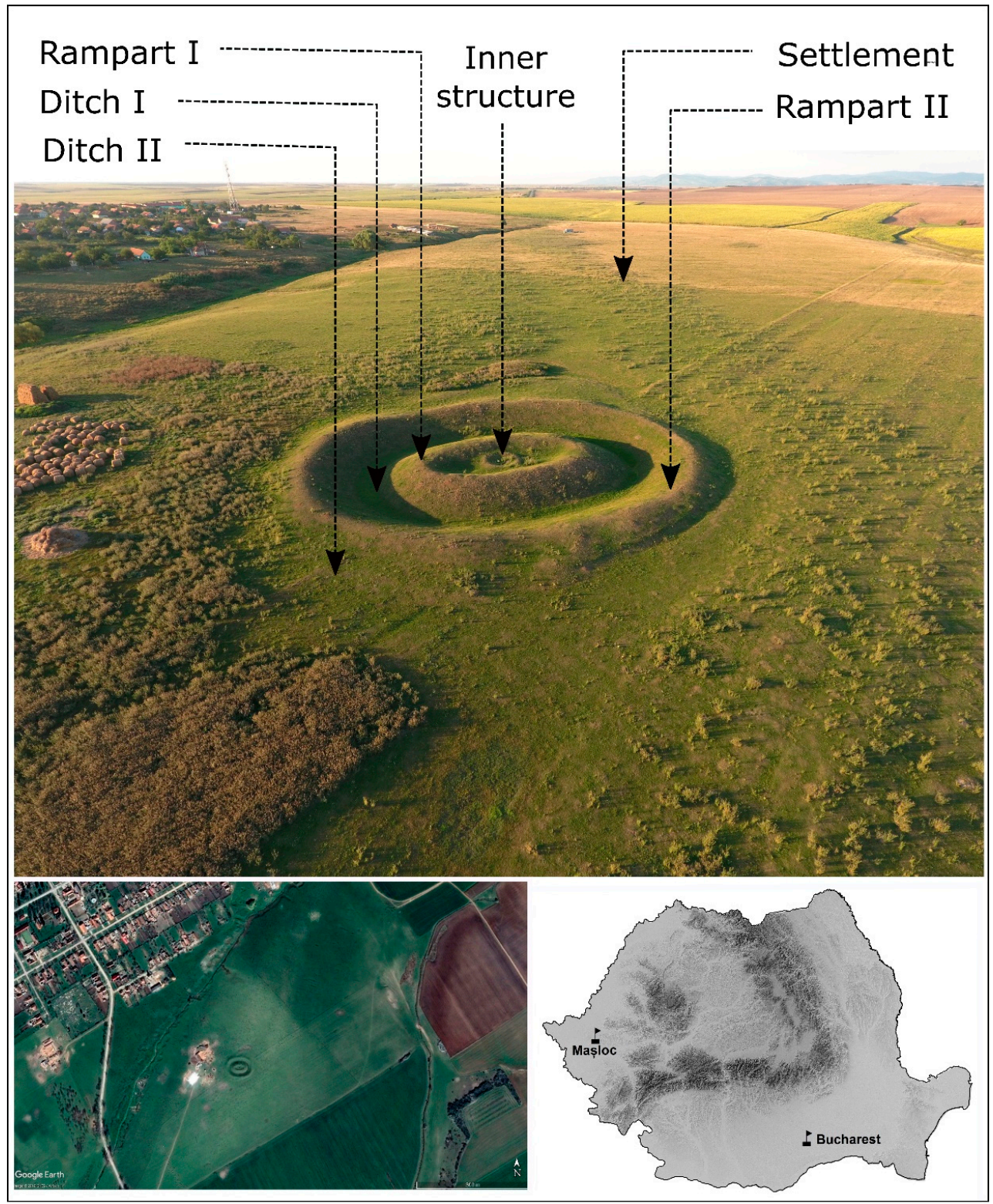

Figure 2. The medieval site of Mașloc "Șanțul Turcilor" (drone photography (top), Google Earth image (30.03.2017) of the surroundings (bottom left) and localization (bottom right)).

Mașloc "Șanțul Turcilor" was identified with the lost village of Machalaka. The Machalaka estate was first recorded in 1322 [26]. In 1333, the priest Martin from Machalaka paid 28 banales as papal tithes $[27,28]$. This means that on the Machalaka estate there was a village with the same name, having a church and a Roman Catholic parish. The name means "Macea's house/village" in the Hungarian language. Until the end of the fourteenth century, the region remained property of the crown. By 1394, the king of Hungary had donated the estate to the Szeri Pósafi family $[29,30]$. It remains unclear when castella Machalaka was built.

In 1471, Stephen, the last male member of the family, died. The Szeri Pósafi was extinguished by defectum seminis (the disappearance of the heirs on the male line of succession) and, according to the laws of the kingdom, all family properties, including the Machalaka oppidum (market-town) and castella with its homonymous domain (more than $210 \mathrm{~km}^{2}$ and 9 estates) passed on to the king of 
Hungary, Matthias Corvinus. In turn, the king donated the domain to his favourites [31]. Stephen's widow, Frusina, refused to abandon her properties and the new lords violently occupied also the castella Machalaka in March 1472 [32].

A document that envoys from Lower Austria submitted to the Imperial Diet in Regensburg (3.09.1556) mentioned the name Mancha Laka among the fortifications conquered by the Ottomans in 1552 [33].

Immediately after the expulsion of the Ottomans in 1716, the first Habsburg conscription found 14 houses at Mas(ch)lok (1717) [34,35], and the maps of the Lipova (1718) [36] and Timișoara (1720) districts [37] show the village of Mac(k)slok on the right bank of the Berexova River (now Beregsău), $2 \mathrm{~km}$ south-southwest from the medieval village of Machalaka. This village is accompanied by two other praedia (praedium - the territory that belonged to an abandoned village) of the same name. We suspect that this was the location of the Ottoman-era village.

The village was abandoned until 1743 [38]. In 1770, German settlers raised another village called Blumenthal close to the medieval oppidum [39]. The seal of the village from 1833 indicates the double name of the village: Blumenthal (German)/Máslak (Hungarian) [40]. Only the name of Máslak remained to become Maşloc (Romanian) after the First World War. We observe in this case a toponymic continuity without a continuity of habitation on the same spot and a phonetic transformation of the toponym Machalaka in Maslok (Mașloc) during the Ottoman period (1552-1716).

\section{Materials and Methods}

\subsection{Geomorphometric Analyses}

In order to understand why the settlement of Mașloc emerged where it did, the landscape parameters of its surrounding areas need to be thoroughly analysed. The geographical parameters were derived using a Lidar DEM (1 m resolution) provided by the Banat Waters Administration (ABA BANAT). Extracting the morphometry from digital elevation models (DEMs) is one of the most important operation in digital geomorphology [41-43]. Primary derivatives were automatically generated using Spatial Analysis Toolbox in ArcGIS v. 10.2 (ESRI, 2013). Lidar DEM is a powerful data source for archaeological analysis $[44,45]$. The DEMs, through morphometric parameters, can easily explain the land conditions for an optimum location of a living site. The slope and aspect along with altitude (and topographic profiles) have a high contribution for quantitative analysis and a good interpretation of the geographical results [41].

\subsection{Planet Labs Satellite Images}

Planet Labs [46] launched the first Dove satellites on 14 February 2017. The satellite fleet of Planet Labs consists of more than 200 polar orbit 3U cubesats, 15 additional SkySats and five RapidEye satellites. This study employs PlanetScope images generated by satellites going around the Earth in two Sun-synchronous orbit configurations (at an altitude of $475 \mathrm{~km}$ ) with a ground sampling distance of $3.7 \mathrm{~m}$ [47]. The spectral resolution of PlanetScope imagery covers the blue, green, red and near infrared wavelengths of the electromagnetic (EM) spectrum. The complete specifications of Planet Labs Imagery are available in the "Planet Imagery Product Specification" (https://assets.planet.com/docs/combined-imagery-product-spec-april-2019.pdf, visit of 26 August 2019). Planet Labs runs a program in which the company offers 5000 square/km monthly for basic educational and research purposes, $15 \mathrm{~Tb}$ /year for departments (Grantees and research teams), and $100 \mathrm{~Tb} /$ year for campuses (Professors, administrators and your entire campus). All the information can be consulted at the following link: https://www.planet.com/markets/education-and-research/. For other purposes than research, Planet Labs operating prices that can be obtained through personal or institutional inquiries. For more detailed comparations in the benchmarks of Satellites Image Services, please refer to the paper of Sozzi et al., published in 2018 [48]. 
This study employed three images acquired in June 2017, April 2018 and August 2018. The purpose of these different times of the year is to observe the highest contrast between site boundaries and its nearby surroundings on the basis of vegetation and soil indices (Table 1).

Table 1. Details about the PlanetScope images used in the study.

\begin{tabular}{cccccc}
\hline & Name & Acquisition & Sensor & Orbit Direction & Resolution \\
\hline IMG 1 & 20170602_084526_0e26_3B_AnalyticMS & 2017-06-02T08:45:26+00:00 & Optical & Descending & $3 \mathrm{~m}$ \\
\hline IMG 2 & 20180822_083312_0f4d_3B_AnalyticMS & 2018-08-22T08:33:12+00:00 & Optical & Descending & $3 \mathrm{~m}$ \\
\hline IMG 3 & 20180411_101735_0c54_3B_AnalyticMS & 2018-04-11T10:17:35+00:00 & Optical & Descending & $3 \mathrm{~m}$ \\
\hline
\end{tabular}

\subsection{Physical Properties and Description of Vegetation Indices}

The basic principle of calculating a vegetation index is that plants absorb different amounts of solar radiation depending on the wavelength range of the EM spectrum [2,49,50]. Plant growth conditions determine the amount of solar radiation that will be reflected to the atmosphere and thus registered by the satellite sensors. It is well known that chlorophyll absorbs light at the blue and red wavelengths and has a strong reflection in the near-infrared and green bands (Figure 3).

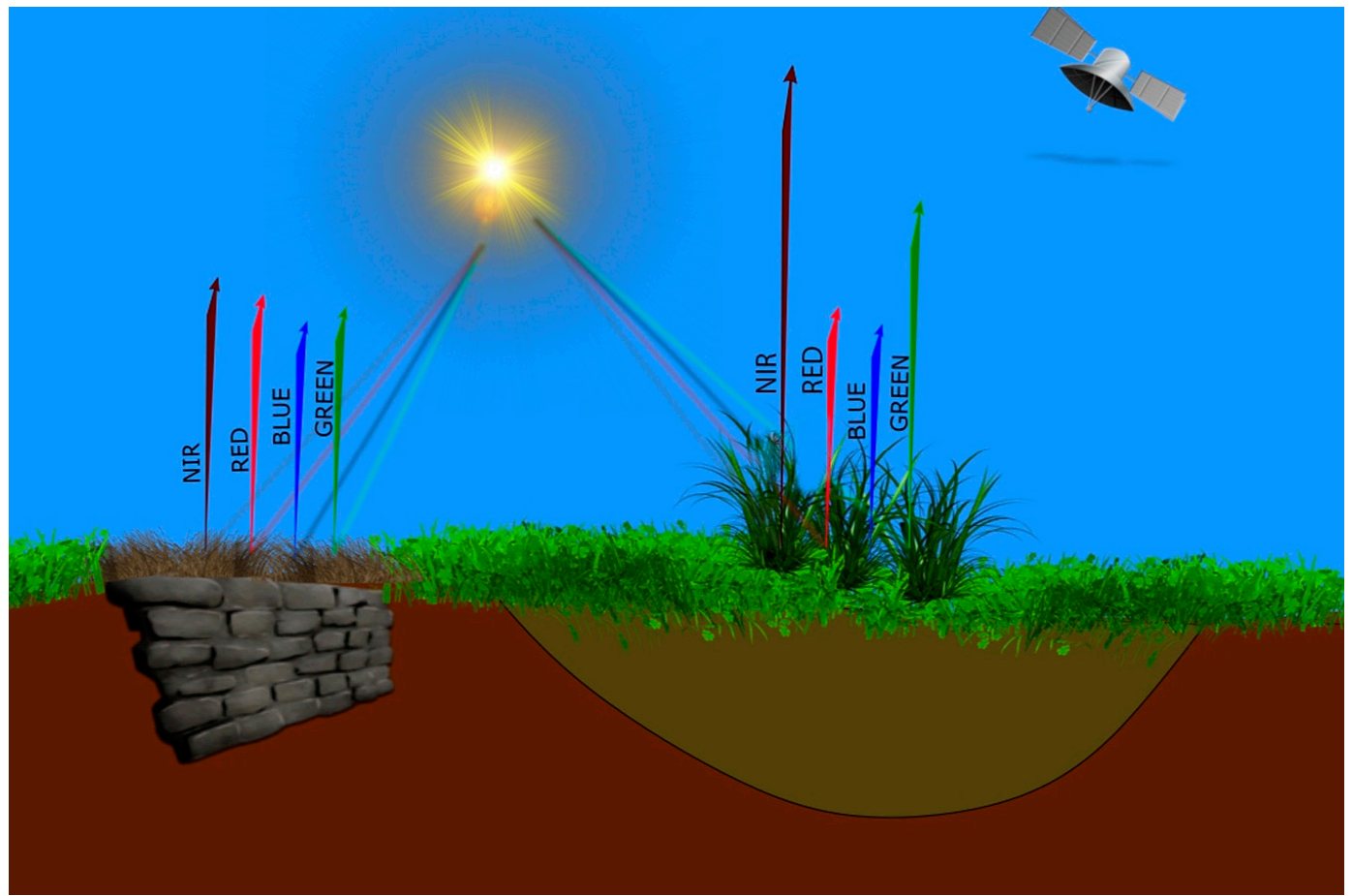

Figure 3. The physical principle of how vegetation indices are calculated. The near-infrared (NIR) and red wavelengths are strongly reflected in areas with higher or denser vegetation.

For calculating vegetation indices, the study used the best known slope and distance-based algorithms available in Quantum GIS 3.8 Zanzibar (Table 2). There is an abundant commentary about these algorithms and the more general vegetation indices [51-53] as well as their archaeological applications [2,9,50,54-56]. Table 2 summarizes the algorithms along with the corresponding bibliographical references.

Together with vegetation index calculation, a simple image fusion was performed in ERDAS 5.1 by using high pass filter (HPF) resolution merge under the pan sharpen tool. The high-pass filter merge function combines resolutions of two images in order to generate a detailed representation of spectral characteristics of a certain scene or part of a satellite image [57]. 
Table 2. Vegetation and soil indices used to identify the full extent of Mașloc "Șanțul Turcilor" medieval village.

\begin{tabular}{ccc}
\hline \multicolumn{3}{c}{ Slope-based vegetation indices } \\
\hline Ratio Vegetation Index (RVI) & Ratio $=\frac{\mathrm{NIR}}{\mathrm{R}}$ & {$[58]$} \\
\hline Normalized Difference Vegetation Index (NDVI) & $N D V I=\frac{\mathrm{NIR}-\mathrm{R}}{\mathrm{NIR}+\mathrm{R}}$ & {$[59]$} \\
\hline Transformed Vegetation Index (TVI) & $T V I=\sqrt{(\mathrm{NDVI})+0.5}$ & {$[60]$} \\
\hline Distance-based vegetation indices & \\
\hline Perpendicular Vegetation Index (PVI) & $P V I=\sqrt{(R g g 5-R p 5)^{2}+(R g g 7-R p 7)^{3}}$ & {$[61]$} \\
\hline Perpendicular Vegetation Index 1 (PVI1) & $P V I 1=\frac{a N I R-R+b}{\sqrt{a^{2}+1}}$ & {$[62]$} \\
\hline Perpendicular Vegetation Index 2 (PVI2) & $P V I 2=\frac{N I R-a R+b}{\sqrt{1+a^{2}}}$ & {$[63]$} \\
\hline Perpendicular Vegetation Index 3 (PVI3) & $P V I 3=a N I R-b R$ & {$[64]$} \\
\hline Difference Vegetation Index (DVI) & $D V I=a N I R-R$ & {$[61]$} \\
\hline Soil Adjusted Vegetation Index (SAVI) & $S A V I=\frac{N I R-R}{N I R+R+L}(1+L)$ & {$[65]$} \\
\hline Transformed Soil Adjusted Vegetation 1 (TSAVI1) & $T S A V I 1=\frac{a(N I R-a R-b)}{R+a N I R-a b}$ & {$[66]$} \\
\hline Transformed Soil Adjusted Vegetation 2 (TSAVI2) & $T S A V I 2=\frac{a(N I R-a R-b)}{R+a N I R-a b+X\left(1+a^{2}\right)}$ & {$[67]$} \\
\hline
\end{tabular}

\subsection{UAV Survey}

The UAV aerial campaign at Machalaka oppidum was used to obtain a photogrammetric Digital Surface Model of the site. Image capture was achieved by using a DJI Phantom 4 quadcopter equipped with a stock 1/2.3" CMOS, 12.4 Megapixel sensor with FOV $94^{\circ} 20 \mathrm{~mm}$ ( $35 \mathrm{~mm}$ format equivalent) $\mathrm{f} / 2.8$ lens. One hundred and forty-four vertical photographs were captured in total.

Agisoft PhotoScan 1.4.0 workflow (Figure 3) was used to obtain a digital surface model (DSM) of the site using the structure from motion (SfM) algorithm $[22,23,68]$. The images were rectified through the use of 20 ground control points (GCPs), measured with an RTK (Real-time Kinematic) GPS. We obtained a set of photogrammetric data covering a surface of ca. 50 ha. The horizontal resolution of the orthophotomap was $5.25 \mathrm{~cm} /$ pixel and $34.5 \mathrm{~cm} /$ pixel for the digital surface model. The DSM was exported as a GeoTIFF and processed in ArcGIS 10.2. (ESRI, 2013). The DSM was used to validate the vegetation indices by allowing us to measure the hight of plants spread along the medieval village outline and also allowed us to compare the vegetated areas with the geophysical results.

\subsection{Geophysical Survey}

The geophysical measurements (excepting the gridded electrical resistivity tomography (ERT) survey) were already published and described in detail in a research article published in Archaeological Prospection journal [24].

Magnetic measurements were carried using the Geometrics G-858 total field dual-sensor caesium magnetometer for ground survey and the Geometrics G-857 proton magnetometer as a base station for diurnal corrections. Six hectares were investigated by using the sensors of the caesium magnetometer in a horizontal configuration with $1 \mathrm{~m}$ separation. The gridded survey was performed by walking in zigzag along parallel transects. A more detailed survey was performed in a $40 \times 40 \mathrm{~m}$ grid overlaying what was considered a household. For this survey we have used the sensors of the caesium magnetometer were used in a vertical configuration (gradiometer) with $1 \mathrm{~m}$ separation. The data processing was conducted in specialized software as MagMap2000 v. 5.00, MagPick v. 3.25, TerraSurveyor v. 3.0.36.0 and Surfer v. 11.2.848 [24].

Electrical resistivity tomography (ERT) data were collected using a GeoTom MK8E1000 high-resolution multielectrode system along a transect over the ramparts and ditches in order to describe the internal structure of them. The measurements were carried out using a Wenner array with 50 collinear electrodes at $2 \mathrm{~m}$ spacing [24]. Additionally, this study includes a gridded electrical 
resistivity survey ( $1 \mathrm{~m}$ distance between the grid line and $0.5 \mathrm{~m}$ electrode spacing along the profile) over a house highlighted by magnetometry. The gridded ERT survey was completed using 16 ERT parallel profiles, $1 \mathrm{~m}$ apart with a $0.5 \mathrm{~m}$ electrode separation. This survey was not presented in Hegyi et al. 2019. The ERT measurements were processed using Res2Dinv v. 3.55, ZondRes2D v. 5.1, ZondRes3D v. 5.0 and Voxler v. 4.2.584.

Ground-penetrating radar (GPR) investigations were completed on the same transect as ERT using the RAMAC GPR system from MalåGeoSciences, equipped with a $100 \mathrm{MHz}$ centre frequency rough terrain antenna (RTA). For processing the data, Reflex v. 6.0 was used.

\section{Results}

\subsection{Geomorphometrically Characterization of the Medieval Village Location}

The altitude difference between the site area and its surroundings is around $60 \mathrm{~m}$. The altitude values increase from south to north, reaching a maximum value of about $195 \mathrm{~m}$ in the area of the river's springs (Figure 4a). Analysing the profile line that goes through the site, the valleys that border the plateau have an asymmetric profile (Figure $4 \mathrm{~d}$ ), distinct for this part of the Vinga Plain. The slope model (Figure $4 \mathrm{~b}$ ) corroborates the location of the medieval village on a relatively flat area. The slope under $2^{\circ}$ is most dominant; more than $53 \%$ of the slope model belongs to that class. Larger slope values are distributed on the sides of the valleys, all under $25^{\circ}$. The aspect parameter is also important for the location of the site. Around 70\% of the hill slopes are sunny, oriented towards a south-southwest orientation, or half sunlit, with west-southwest exposure. The particular orientation for the afferent surface of the built-up area is mostly half sunny (Figure 4c). The gentle landforms, the presence of springs, the fertile soils and topo-climatic characteristics, the inclusive leeward position, and the Beregsău river neighbourhood all demonstrate excellent geographical conditions for the settlement.
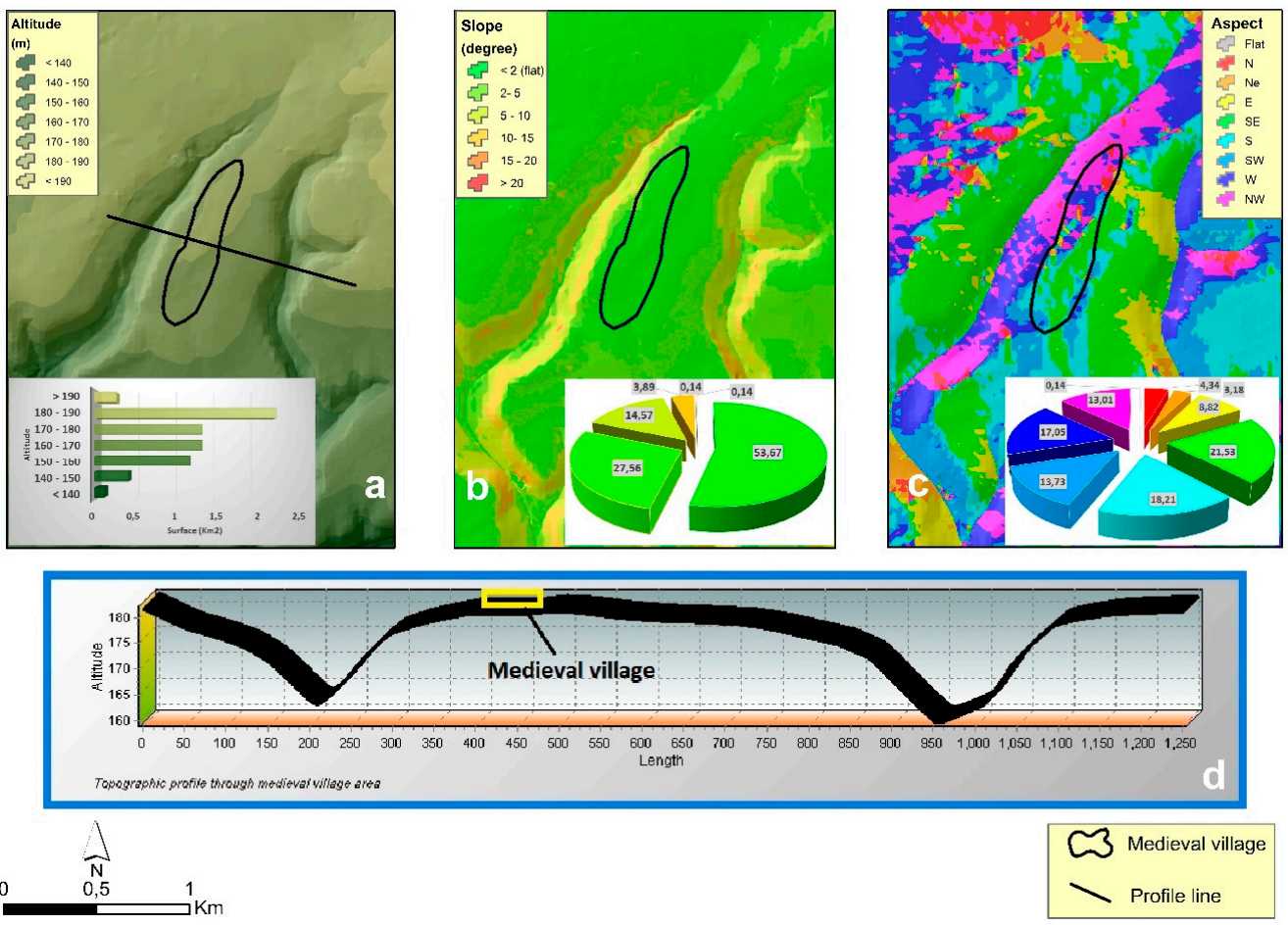

Figure 4. Morphometric parameters of the "Șanțul Turcilor" site: (a) hypsometry (altitude); (b) slope; (c) aspect; (d) topographic profile. The geographical parameters were derived using a Lidar DEM (digital elevation model, $1 \mathrm{~m}$ resolution) provided by the Banat Waters Administration (ABA BANAT). 


\subsection{Integration of Vegetation Indices with Geophysics and Structure from Motion}

Figure 5 presents the results obtained with the perpendicular vegetation index (PVI) algorithms. Satisfying outcomes are generated with all PVI algorithms on the PlanetScope image acquired in June 2017. PVI 3 and PVI 4 provided good results in the image of April 2018 and PVI 2, PVI 3 and PVI 4 in the image of August 2018. Soil adjusted vegetation index (SAVI) (Figure 6) generated good results only for the image dating from June 2017; the results for the images acquired on April 2018 and August 2018 are less satisfying. The best results for all three images are those obtained with transformed soil adjusted vegetation 1 (TSAVI1), which precisely revealed the extent of the medieval village. The transformed soil adjusted vegetation 2 algorithm worked well only for the image from June 2017, but still highlights the village layout on the other images (Figure 6).
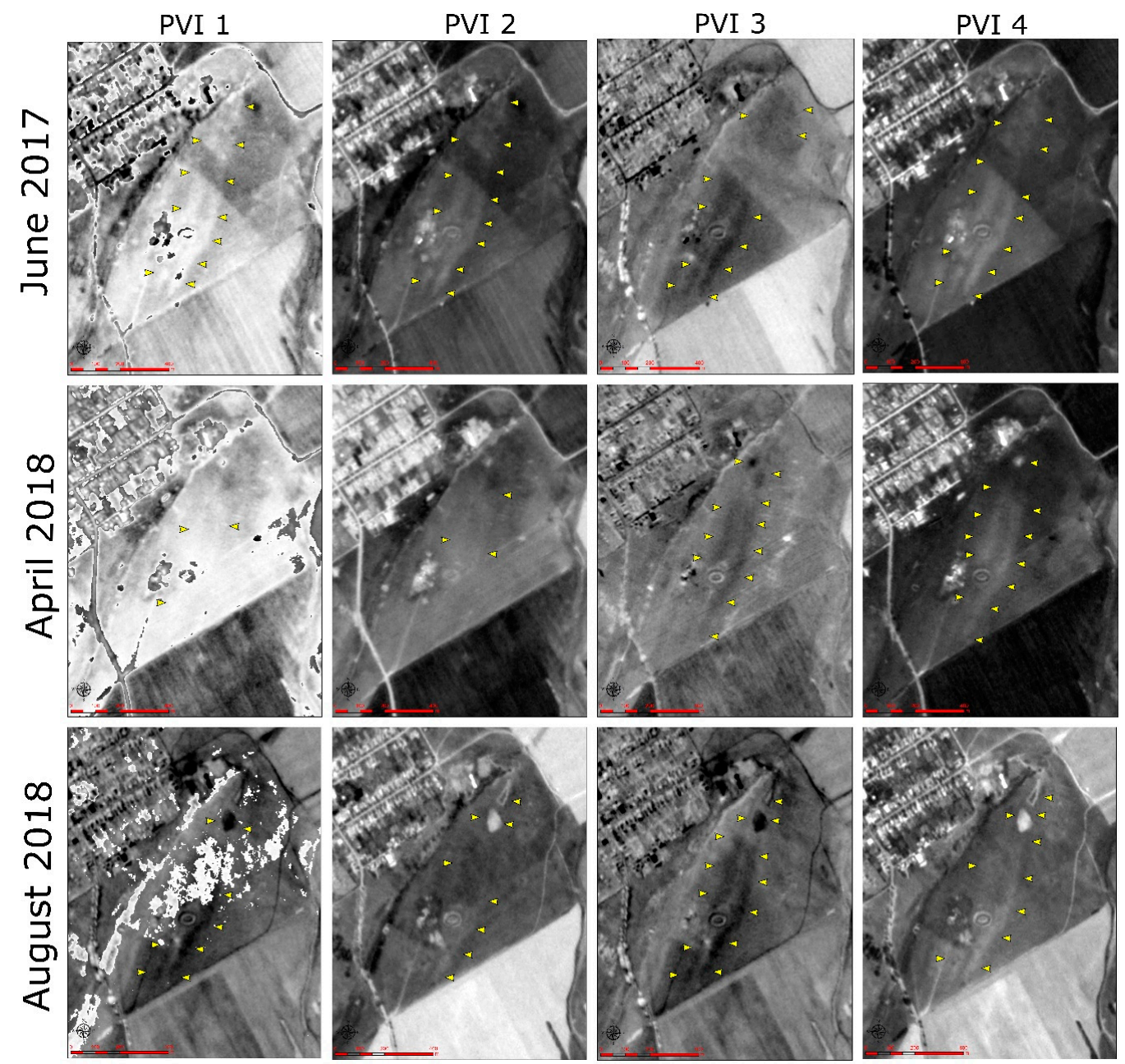

Figure 5. Results of PVI 1, PVI 2, PVI 3 and PVI 4 algorithms for the three different satellite image captures. The yellow arrows indicate the features shown in each image.

The ratio vegetation index (RVI), normalized ratio vegetation index (NRVI), difference vegetation index (DVI) and normalized difference vegetation index (NDVI) algorithms generated the best results for the June 2017 image. The same was true for the PVI and SAVI/TSAVI results. For the April 2018 image, RVI and NDVI allowed the identification of the village boundaries, while for the August 2018 image, DVI yielded relatively satisfactory results (Figure 7). 

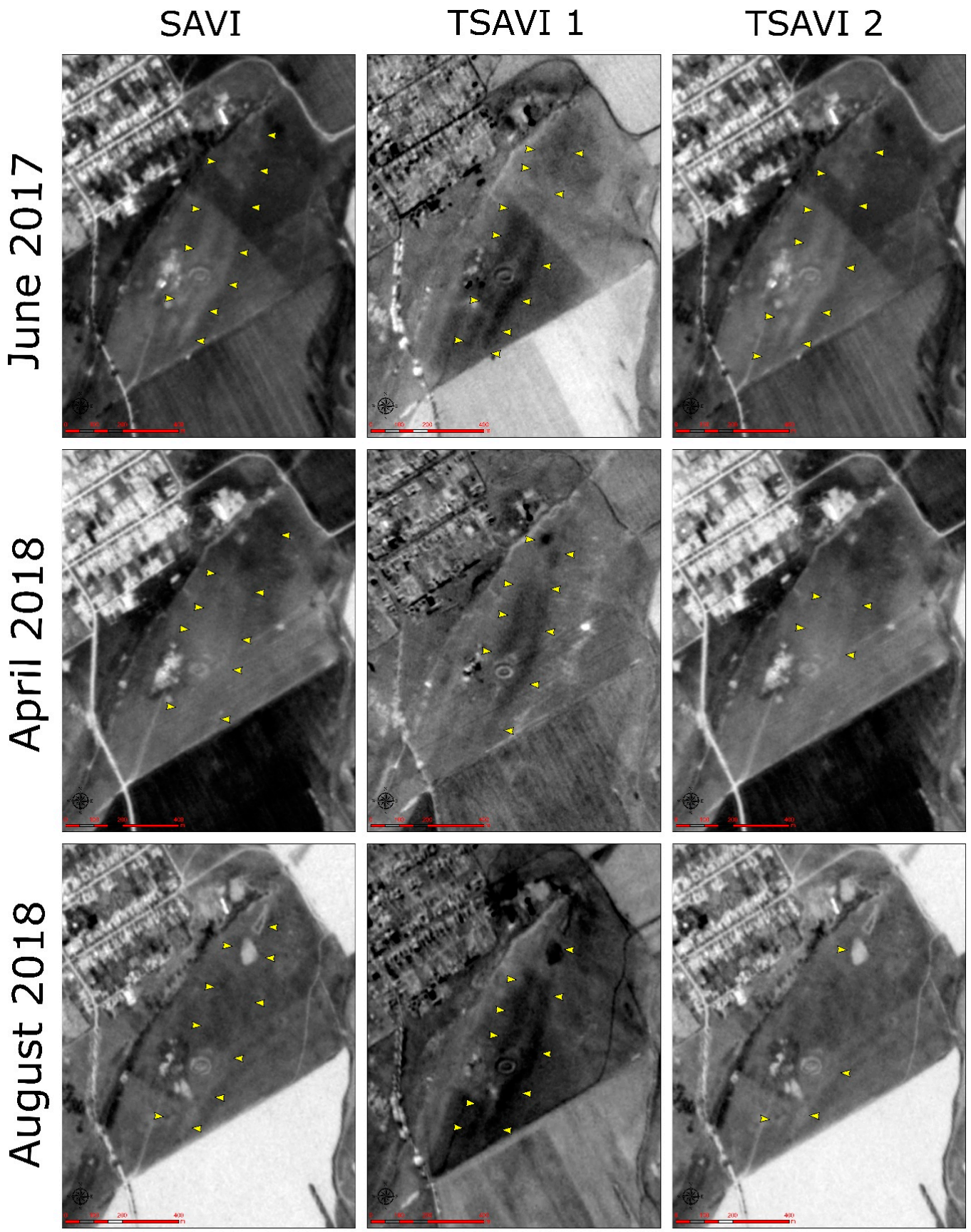

Figure 6. Results of SAVI, TSAVI 1 and TSAVI 2 algorithms. The yellow arrows indicate the features shown in each image.

A simple image fusion of Planet images (Figure 8) clearly delineates the extent of the medieval village, which was developed along a central axis running from the northeast to the southwest. The entire area of the village visible by means of vegetation marks is $114268 \mathrm{~m}^{2}$ (about $11.4 \mathrm{ha}$ ).

The best results for the land use patterns were obtained from the drone survey and structure from motion (SfM). A high-resolution orthographic mosaic $(5.2 \mathrm{~cm} /$ pixel) and a digital surface model $(34.5 \mathrm{~cm} / \mathrm{pixel})$ were created by such means. The results of SfM were used for the validation of Vegetation Index algorithms and can reveal the extent of the village together with other information related to historic land use. 

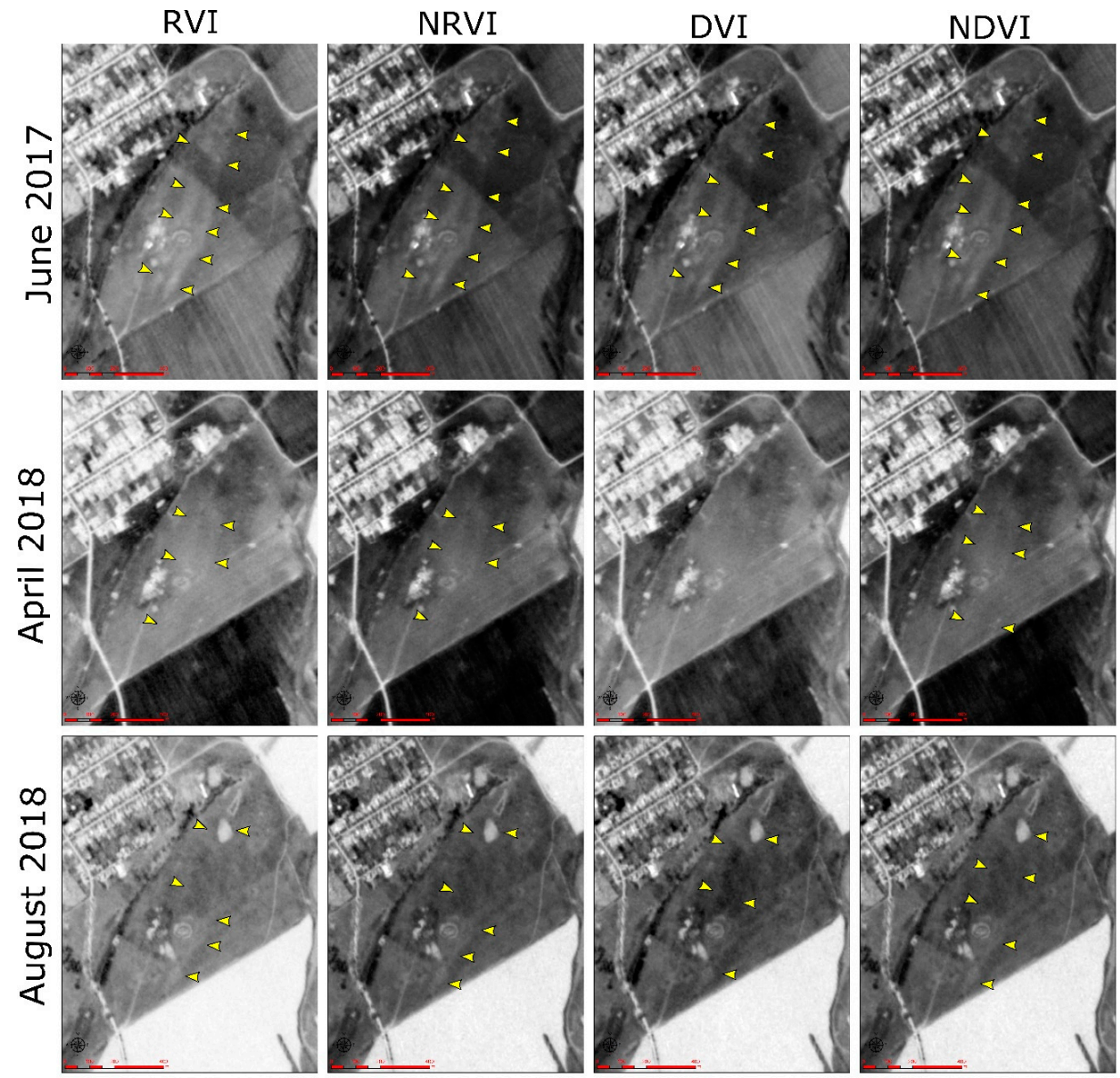

Figure 7. Results of RVI, NRVI, DVI and NDVI algorithms. The yellow arrows indicate the features shown in each image.
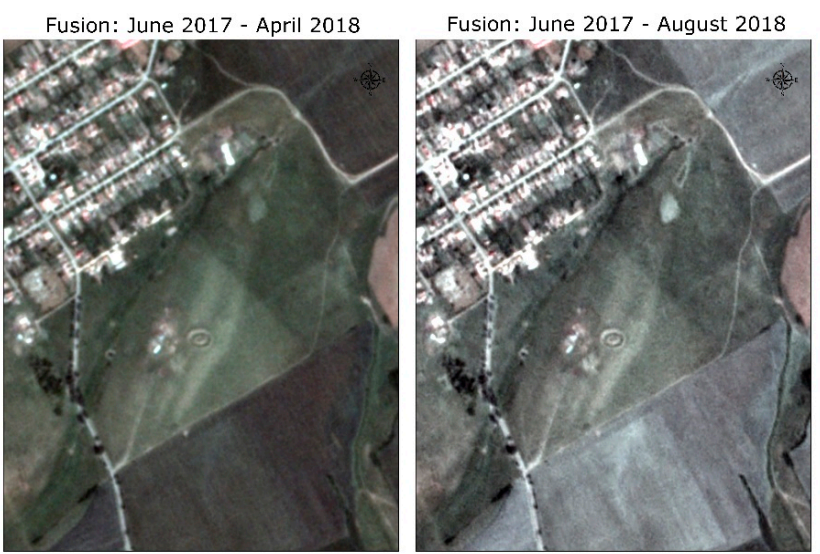

Fusion: April 2018 - August 2018

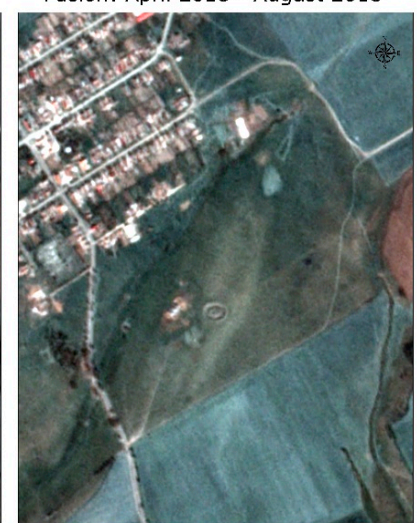

Figure 8. Image fusion (from left to right: combination June 2017-April 2018, June 2017-August 2018 and April 2018-August 2018).

The extent of the medieval village was determined by identifying areas covered by Euphorbia, a flowering plant commonly known as spurge, which was first described by Carl Linneaus in 1753 (Linnaeus, 1753). The growing pattern of the plant within the site depends upon the archaeological constructions underneath. Although Euphorbia has not been examined for archaeological site detection in prior research, our results suggest this may be a good proxy for identifying other buried archaeological features in this region. Further botanical and archaeological studies are required for this correlation. 
Furthermore, comparing the resulting digital surface model and orthophotomosaic with the magnetic map demonstrates that the vegetation growth is higher in areas where the magnetic anomalies are located. In Figure 9, one anomaly is analysed in comparison with the digital surface model. In areas with high magnetic susceptibilities, we can observe that the plants are 25 to $40 \mathrm{~cm}$ taller (Figure 9B,C) than others in the region. This situation is highly visible on and near the positive anomalies which exceed $10 \mathrm{nT}$ in range. It is also obvious that higher vegetation sections do not pinpoint linear features (namely walls). Instead, they are spread over patches of land, most probably over archaeological structures, where more organic material has been retained over time.

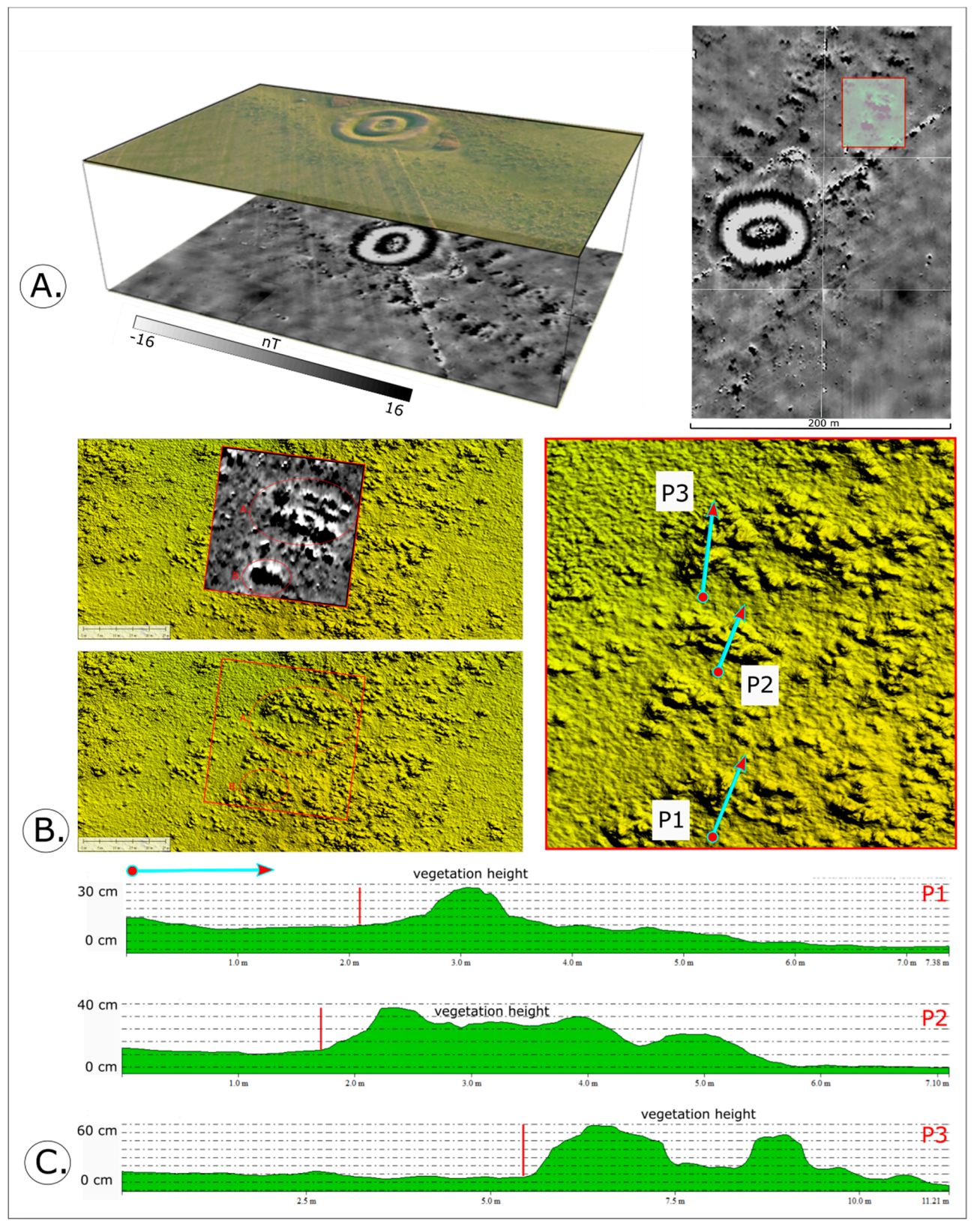

Figure 9. (A) Magnetic measurements in comparison with orthophotomosaic; (B) Comparison of magnetic measurements with vegetation height-it can be easily observed that the vegetation has a different growth pattern in the areas where magnetic anomalies exist (positive magnetic anomalies, represented with black colours, suggest a disturbance in the topsoil containing more soil nutrients for plants). (C) Vegetation profiles show that the growth rates over the magnetic anomalies is higher than their surroundings. 
Figure 10A,B presents the results of the ERT gridded survey (in depth sections) in association with the chosen magnetic anomaly. The positive magnetic anomaly $(10 \mathrm{nT})$ corresponds to resistivities values between $50-200 \Omega / \mathrm{m}$ and in some areas $>200 \Omega / \mathrm{m}$. The linear distribution of these resistivity values suggests the existence of a considerable discontinuity in the type of the soil. Hence, these anomalies can be interpreted as part of a dwelling foundation. However, because of the ERT gridded survey covered only a small area, further investigations are required and even archaeological excavations. The discontinuity in soil layers proves the existence of houses with a well-defined wall structure for which most probably foundation ditches were required. The mixed material produced by the house remains, together with the former intense human habitation, can provide better condition for plant growth. It's clear that the plants covering the archaeological site in discussion had better condition of growth where the medieval houses were located (Figure 9).

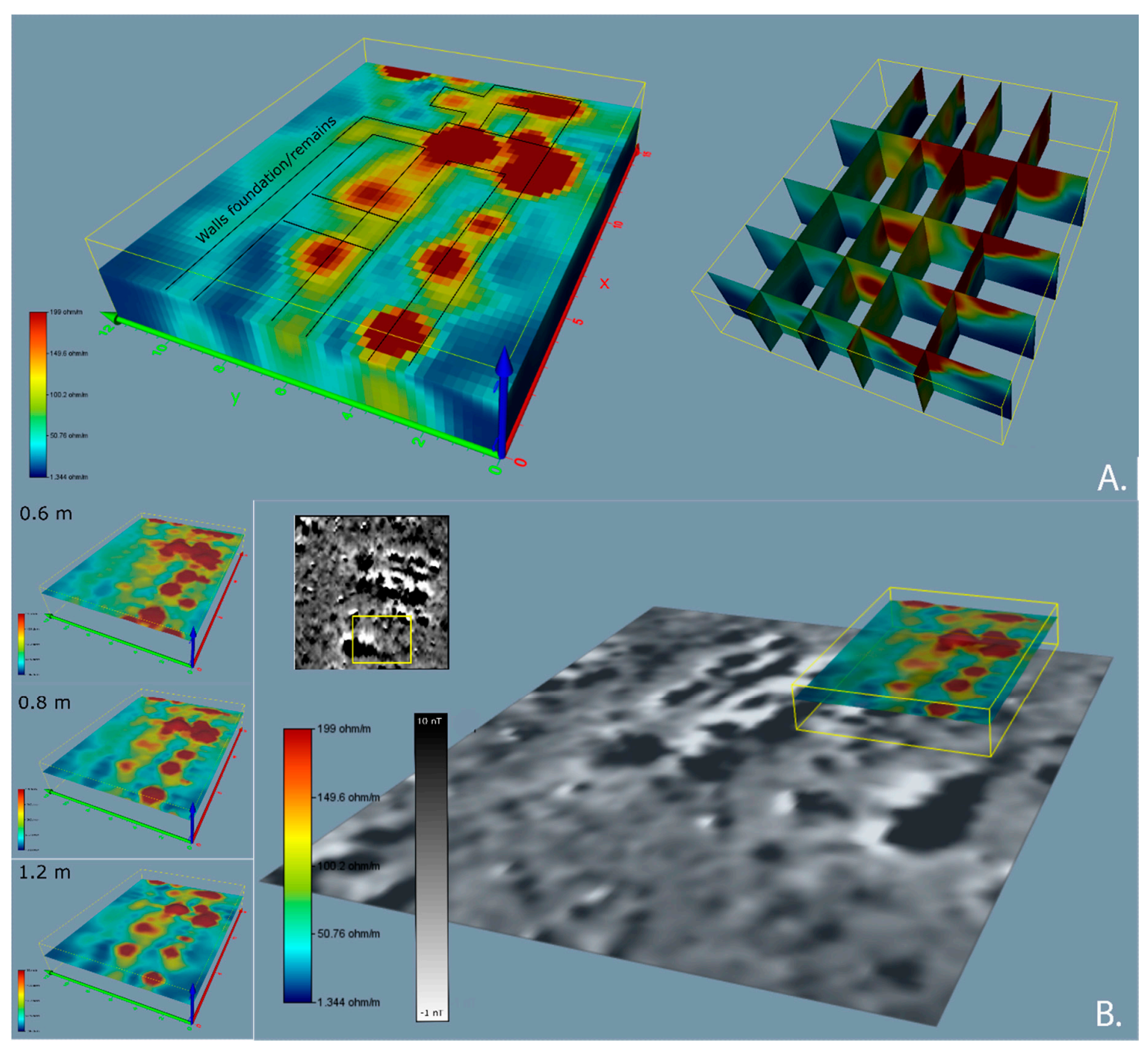

Figure 10. Electrical resistivity tomography (ERT) gridded survey: (A) Resistivity model (left), YZ plane (sagittal) and XZ plane (coronal) slices; (B) depth slices (left) and depth slice overlaying magnetic map (right).

\section{Discussions}

Further examination of the orthophotograph and the digital surface model (Figure 11A) of the medieval Machalaka reveals more information about the layout of the settlement. Upon looking closer, one can even recognize the remains of the medieval field system, represented by a series of parallel stripes with slightly different elevations of 10 to $30 \mathrm{~cm}$. Even if these stripes are not that well preserved, 
the micromorphology and their distribution highlight the purpose they served. The stripes most likely represent the boundaries of plots associated with the houses. Dividing parcels in this way continues to be a popular practice in Banat's rural areas at present (Figure 12B). People dig a linear ditch less than $1 \mathrm{~m}$ deep (most of the time around $0.5 \mathrm{~m}$ in depth) around the boundaries of the parcel. The soil extracted is placed on one side of the ditch (inner or outer) creating a linear elevated area where a fence is placed. Upon closer look, these stripes are also present on the magnetic map as faint linear anomalies; they would be otherwise impossible to interpret without this complementary analysis (Figure 11B). Overlying the magnetic anomalies on the digital surface model confirms that each house has a correspondent parcel. More than 30 parcels were digitized by using the digital surface model and the orthophotomosaic (Figure 11B). These stripes are all visible on most satellite images available on Google Earth, but a winter image from April 2012 emphasizes them in the clearest manner (Figure 12A).
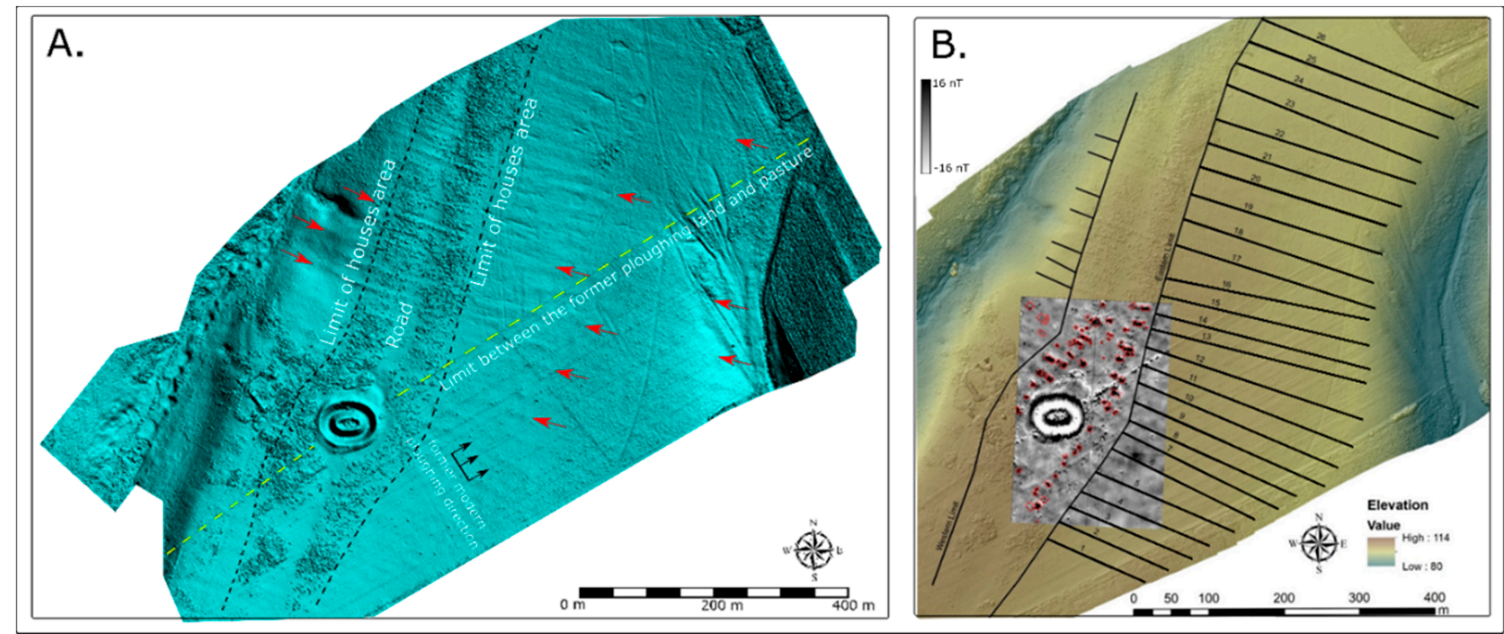

Figure 11. Integration of results of structure from motion (SfM) and magnetometry in combination with DEM: (A) Digital surface model—red arrows indicate the field system of the medieval village; black grouped arrows indicate the former modern ploughing lines; the yellow dashed line represents the limit between the former ploughing area and pasture land; the black dashed lines represent the boundaries of the medieval village highlighted by the vegetation. (B) The digitization of the field system superimposed on the magnetic map (the dwellings are marked in red).

It is possible the pattern was made by old ploughing activity in the area, but it is not very likely, since it would have been aligned in the direction of the shape of the plateau rather than along the magnetic anomalies. Furthermore, there is no sign of visible plough marks on the older declassified satellite images from the 1960s (Figure 13), but the parallel stripes are visible on these images as well. There is a clear differentiation between the more recent ploughing area towards the southeast (before 1989) and the pastureland. Most interesting is that we can also track the stripes inside the ploughed area. The direction of the stripes (perpendicular to the village boundaries), their presence only around the extent of the village and nowhere on nearby fields, and their distinct morphology, which can be seen inside more recently ploughed areas, all sustain the idea that the stripes are boundaries of individual plots associated with the village's houses. A field system is the simplest interpretation for these parallel stripes, but this is a hypothesis that can be tested in future work (e.g., soil samples, ground-tests, etc.). 


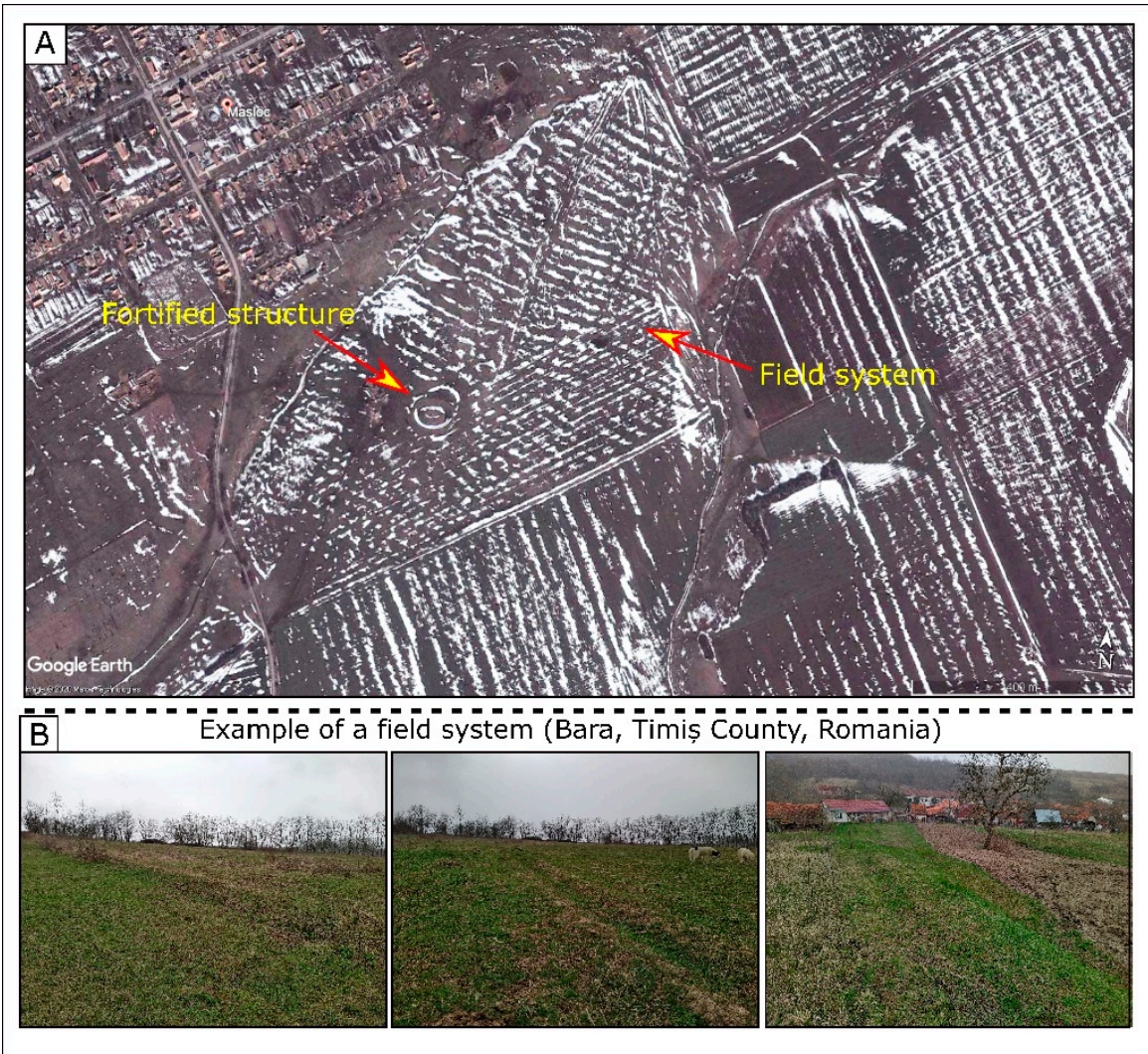

Figure 12. (A) Google Earth satellite image 04 March 2012 (brightness added). The field system is easily observed as the sedimentation of snow follows the direction of the parallel stripes; (B) Example of contemporary field system from Bara village, Timis County, Romania.

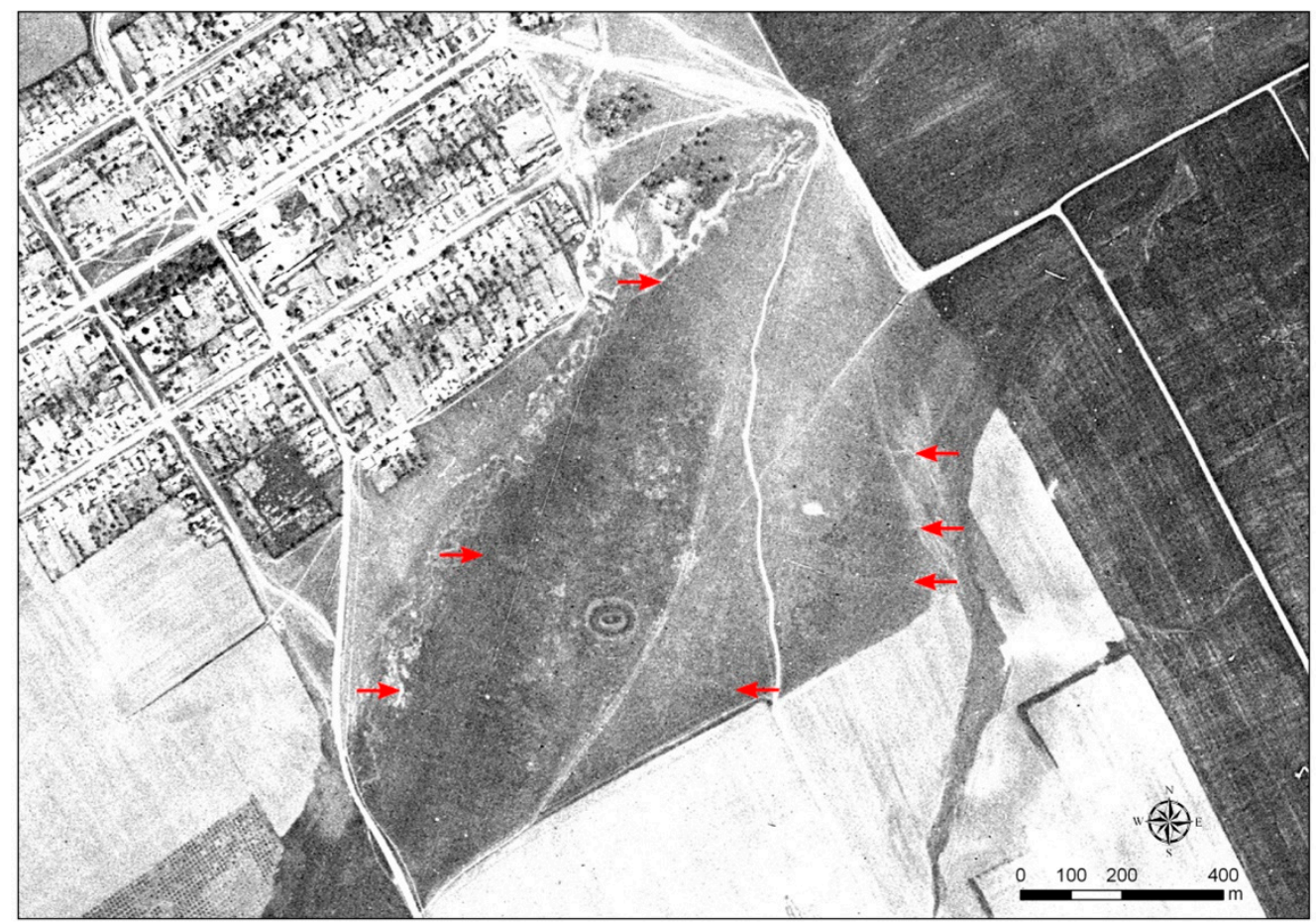

Figure 13. Georeferenced 20.05.1964 Corona spy satellite image DZB00400800010H024001_a. Red arrows indicate the presumed field-system visible as a cropmark. No sign of ploughing at that time, indicating the entire area of the medieval village was pastureland for the modern Mașloc village. 
The stripes observed on the digital surface model suggests Machalaka medieval market-town medieval village had individualized parcels behind the houses, showcasing certain rules on daily life and land use practices. Most probably, the lots were used for practicing subsistence agriculture and agro-pastoral activities.

Furthermore, the high resolution of the digital surface model allowed a clear image of the fortified central structure (Figure 14) located in the middle of the settlement. The fortification consists of two noteworthy ramparts and two ditches. The circular shape of the fortified manor/church has a span of $6 \mathrm{~m}$, clearly playing a central role in the site layout. The fortification encloses an area of 32 square meters, with the first ditch (D1) being $20 \mathrm{~m}$ wide and $3.5 \mathrm{~m}$ deep (Figure 14). A second outer rampart and a ditch encircle the whole site. The preservation of the internal rampart around the ring structure is most impressive. The long ridge axis measures $30 \mathrm{~m}$ with a width of $15 \mathrm{~m}$. In relation to the current level of the central part, the rampart ridge has an elevation of $1.5 \mathrm{~m}$. The internal ditch has a depth of approximately $3.5 \mathrm{~m}$ and $19-22 \mathrm{~m}$ width.

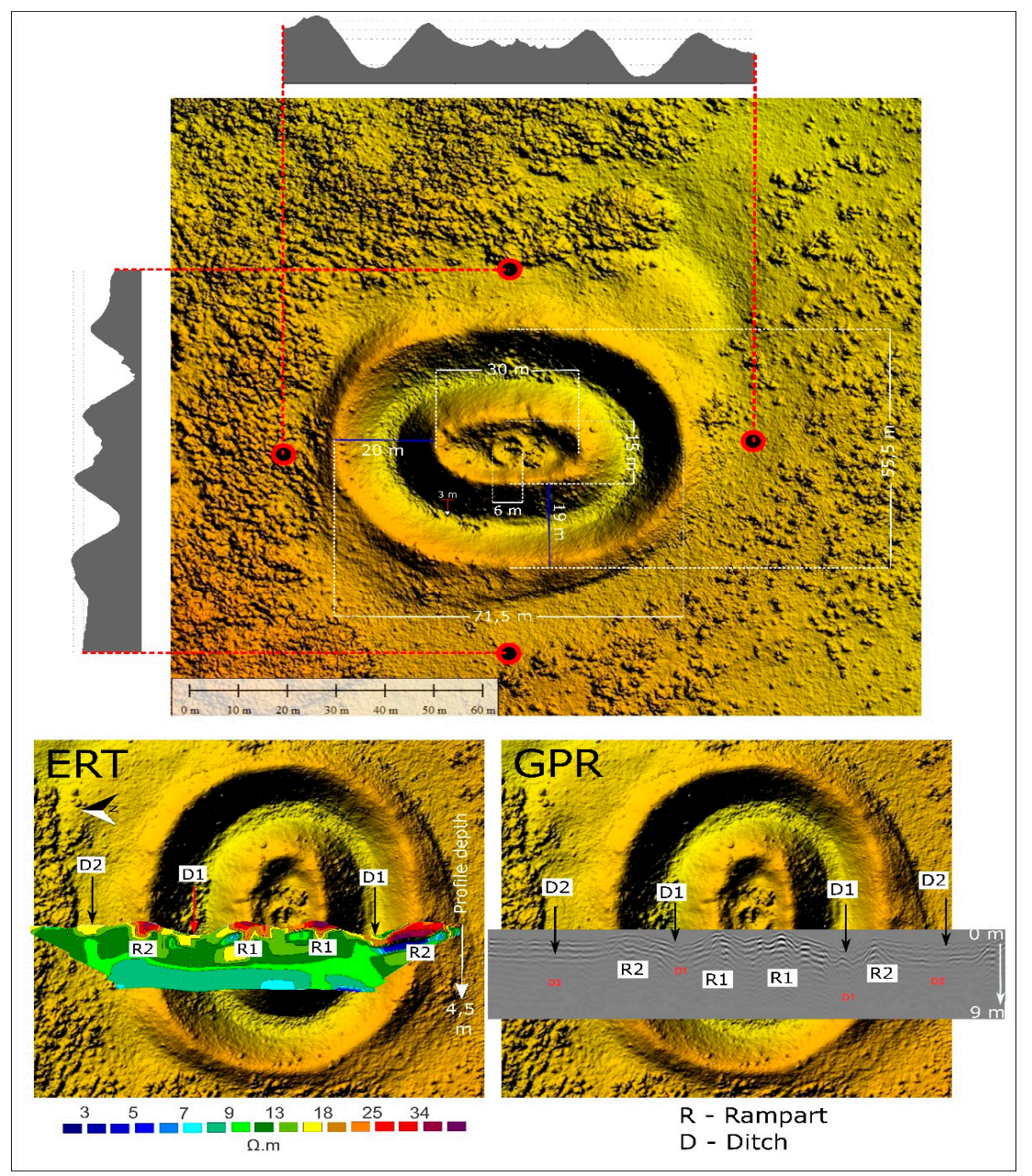

Figure 14. The digital surface model showing today's preservation of the central fortified structure of the medieval village (top). The ERT (bottom left) and GPR (ground-penetrating radar, bottom right) profiles measured over the rampart and ditches highlight a few aspects regarding their morphology. The ramparts are represented by slightly higher resistivity values (ERT) and by stronger EM reflections (GPR) suggesting the remains of a wall or a palisade. Both ERT and GPR profiles allowed the estimation of the real depth of the ditches and proved the existence of a second outer ditch (D2) enclosing the inner structure. 
The ERT and GPR profiles over the fortified system allowed the chance to estimate the real depth of the ditches, confirming the existence of an outer second ditch (D2) (Figure 14) enclosing the central structure. This second ditch was filled and, unfortunately, is not recognizable in the field anymore. Even though the ditch is not visible to the naked eye, its existence was intuited by Liviu Măruia and his team in 2011 [69]. In 2012, Bogdan Condurăţeanu, the manager of Digital Romania 3D Project (www.romaniadigitala.ro), presented a sketch of the central fortified structure after digitizing the ramparts and two ditches (including the outer one highlighted by the ERT and GPR profile) [70].

Numerous small fragments of human bones were found inside the fortification, discovered in the soil on the outer slope of ramparts. These fragments are not associated with other types of architecture, with the exception of sporadic fragments of adobe. It may be possible that they provide evidence of burials dug into the ramparts. Several brick fragments were uncovered in the central enclosure and ditches, in addition to the bones. The distribution of this building material in the area of the fortified assembly is an important indication that suggests the presence of brick walls, at least for the central ring structure.

The results of the research proved to be strikingly similar to traces of hillside terraces with selions (strips of cultivated land) uncovered by archaeological excavations at Tamási (Tolna County, Hungary) [71]. It is not clear how the land was formed and delivered for cultivation, however. Was it formed after the clearance of the forest?

Whatever the case may be, the name of the village incorporates the Hungarian word laka ("house of $f^{\prime \prime}$. This implies that it was initially an isolated farmstead with a small clearing or drainage allowing for the establishment of the nucleated village. Such villages were typical for the later Middle Ages in Hungary (fourteenth to sixteenth centuries), when large estates and a manorial economy dominated the economic landscape of the kingdom [72]. One of the earliest excavations targeting such settlements was carried out at the deserted medieval village of Móric (near present-day Túrkeve, in Jász-Nagykun-Szolnok County, Hungary). Móric was excavated in 1948 and 1949 by István Méri (Méri, 1954). However, neither Móric, nor Szentkirály [73] presented a layout comparable to that identified in the medieval market town of Machalaka. For a formal analogy to the layout of the deserted medieval village of Mașloc, one has to reach far to the northwest, to Dašovice (near Znojmo, in southwestern Moravia, the southeastern part of the present-day Czech Republic). The deserted medieval village identified there by means of field survey dates between the middle of the fourteenth and the middle of the fifteenth century. Its layout consists of two rows of farmsteads along a street with a motte at one end, which may be the fortified manor [74]. The most famous of all deserted medieval villages excavated in southwestern Moravia, Pfaffenschlag (deserted in the 1420s or 1430s), had a similar layout, with a brook instead of a street as the main axis of the settlement [75].

More recent studies regarding the layout of medieval settlements in Bodrog County (in Hungary) and northern Serbia present striking similarities with the one of Mașloc "Șanțul Turcilor". Hence, the medieval village of Arany near Vaskút (Figure 15A) is practically similar, with the exception of the inner structure [76,77]. The plan of the settlement was made using satellite images provided by Google Earth and the digital image of the central structure was drawn based on the cropmarks seen in the summer image presented by Buzás et al. (2019). The village has an almost identical layout with Mașloc "Șanțul Turcilor". The difference is represented by the church in the centre of the village (church), which produced a very clear cropmark; Buzás et al. (2019) also proposed a graphical reconstruction of Arany village by combining remote sensing with historical information. Istvan Pánya further discussed the history of these settelmens in Bodrog County and presented a sketch explaining the layout of Arania village [77].

A similar layout is visible at the Iratoșu (Arad County) medieval site, having a similar central structure, but a considerably larger size than "Șanțul Turcilor" [24,78,79]. Instead of one central street, the medieval settlement in Iratoșu had two streets intersecting in the middle, where the fortified structure was located (Figure 15B). 


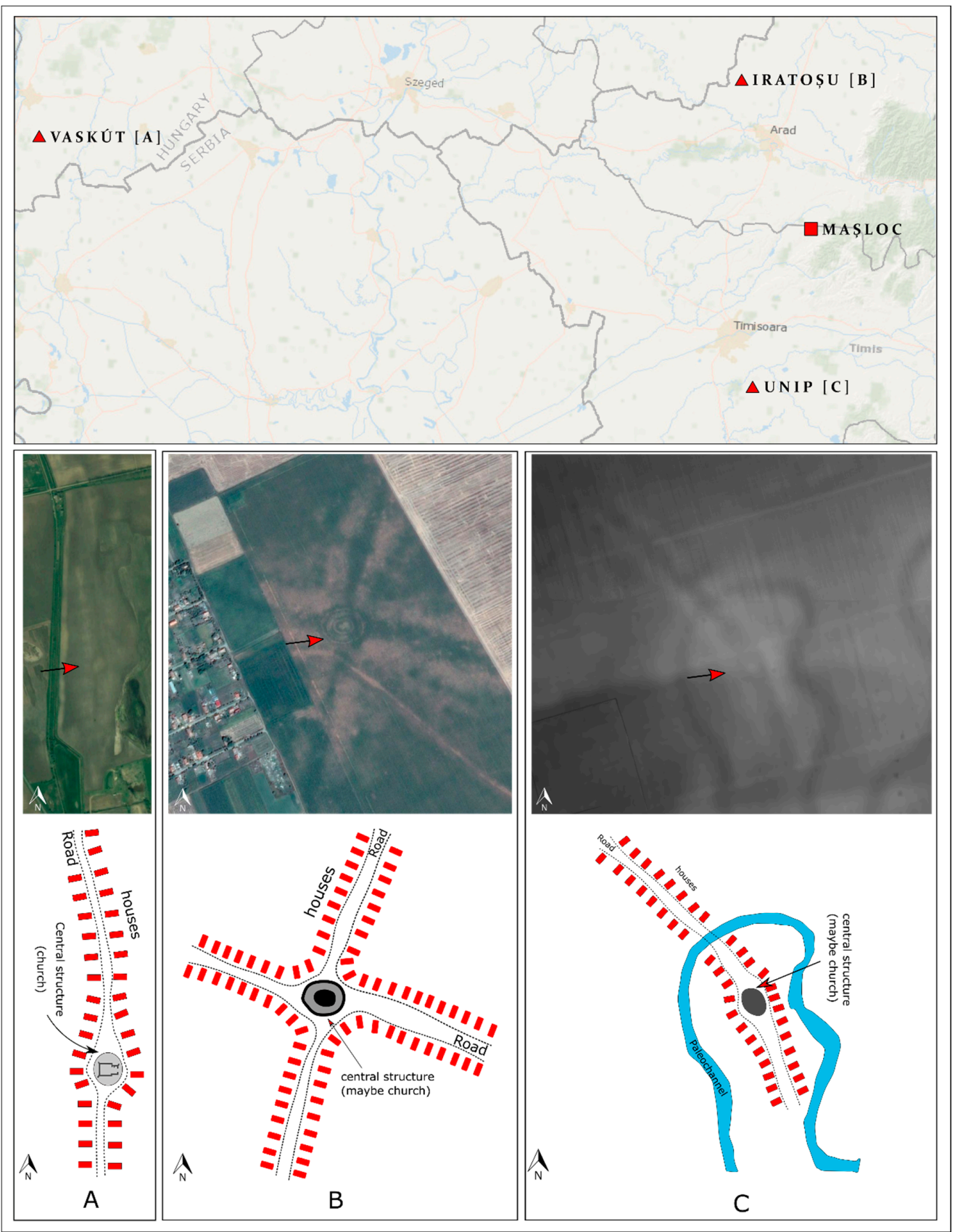

Figure 15. Top image: Location of the discussed medieval village; (A) The medieval village of Arany as seen on a Google Earth satellite image of 04 November 2011 and the corresponding sketch that represents the layout of the village (B) Iratosu medieval village. Google Earth satellite image from 13.08.2013 (the outline of the medieval village is visible as a cropmark) and a hypothetical sketch of the medieval village based on this. (C) Unip medieval village. LiDAR DEM $1 \mathrm{~m}$ resolution. The full extent of the village layout together with the central structure can be traced from Google Earth satellite images (see for example captures of 5.10.2009 and 5.5.2014) and the LiDAR Dem.

Recently, during systematic fieldwork for his doctoral thesis, Cristian Floca identified another medieval village contemporary with Mașloc "Sanțul Turcilor" located within the boundary of the present-day Unip village, near Timișoara. Even if the preservation state is generally poor due to the intensive agriculture practices and different geographical settings, the layout resemblance to Mașloc "Șanțul Turcilor" is uncanny (Figure 15C). More detailed research at this site is in progress. 


\section{Conclusions}

Over the last 15 years, archaeological fieldwork research carried out within the Banat region has identified many medieval fortifications and settlements, none of which has been systematically investigated. Even if a few excavations were performed at some of these medieval sites, the results are still pending publication.

Of all these fortified assemblies, the one from Mașloc easily stands out. Its exceptional preservation, as well as the shape and complexity of its structures, makes it unique in the landscape of medieval fortresses in the Banat region and beyond.

We have successfully managed to estimate the extent of the medieval and its morphology without any archaeological excavation. The longitudinal central axis of the settlement, oriented in a NNE-SSW direction, is superposed on the fortified assembly located at its central part.

The outcomes of this study prove that satellite remote sensing, in this case using Planet Labs satellite imagery, can be a huge asset in developing further investigation for these sites. The layout of these medieval villages can be outlined using soil and vegetation indices, and in turn they can also be proxies for geophysical investigations, as well as for analysing the morphology and shape of each site. The methodological techniques of merging satellite imagery photographs, structure from motion orthophotomosaics, and geophysics have proven a sufficient tool for addressing specific questions about deserted medieval villages from southwestern Romania and potentially the rest of Europe.

Using these results, we have created an artistic reconstruction of the site's layout (Figure 16). After a preliminary sketch in pencil, the drawing took shape by illustrating the way in which houses in the settlement of Mașloc "Șanțul Turcilor" were situated. We are able to understand how the households are distributed perpendicular to the main axis that crosses the entire settlement in the northeast-southwest direction. The centre of the settlement features two possible variants of constructions. The first embodiment (Figure 16A) shows a tower, most probably made of wood. In the second variant (Figure 16B), it is a round fortified chapel, made of brick with earthen or brick walls. Both variants indicate a palisade-like concentric fortification. Based on previous excavations, we can assume that the dwellings constituted households that included the basic dwelling and some annexes for animals or grain storage. The construction system of the houses was probably made of wood while the walls were filled with daub. The lack of concrete data and the absence of any archaeological excavation does not allow us to express this with certainty nor does it offer more details regarding the typology of the houses or construction materials.

Besides the technicalities, the results of this study provide a strong historical impact as it demonstrates that this medieval village was developed under strict topographical rules and it was not an isolated case. Each house was aligned to the main street, having its own delimited plot at the back for agricultural purposes. The settlement's organization allows us to consider that the village was planned under certain construction rules, being the first systematized medieval village in Romania to be documented by the means of applied geosciences.

In the end, the results of this study confirm the description of Engel Pál from his book The Kingdom of St Stephen: The History of Medieval Hungary, 895-1526 (pages 272, 273) [80]:

The irregular, widely dispersed settlements of the early Árpádian period gradually gave way to a new, German type of village, which generally consisted of a single street, with the inner holdings lying on the two sides and their appurtenances dispersed throughout the village territory. The inner holdings as a rule took the form of a long rectangle, with its shorter side facing the street, whence a wide gate led into the court. The house was always constructed on one side of the court. By the thirteenth century the small hovel of the earlier period had been replaced by an oblong house with three rooms. It was generally a wooden construction, adobe and stone not being used for rural buildings before the early modern period. The entrance was in the middle of the house and led into the kitchen, which was equipped with an oven. From the kitchen two other doors led to the living room on one side and to the pantry on the other. The farmyard was beside and behind the house and was joined by a garden, and sometimes also by a small piece of arable land, at the other end. 



Figure 16. The hypothetical reconstruction of Machalaka medieval market-town based on all the information obtained from the results of this study. In the first scenario (A) the village has a tower in the middle, while in the second scenario (B) the fortifications enclose a circular church/chapel. 
Author Contributions: Conceptualization, A.H.; Data curation, A.H., Formal analysis, A.H., F.C., S.F., P.U., A.O. and A.S.; Funding acquisition, A.H.; Investigation, A.H. and C.F.; Methodology, A.H., A.S., C.F., P.U. F.T. and M.P.; Project administration, A.H.; Resources, A.H. Software, A.H., S.T., M.N. and D.M.; Supervision, A.H. Validation, A.H., A.S., F.C. and S.F.; Visualization, A.H., A.S., C.F., A.O., F.T., M.P., S.T., M.N., D.M. and A.S.; Writing - original draft, A.H.; Writing - review \& editing, A.H., A.S. F.C., C.F., S.F., P.U., A.O., F.T., M.P., S.T., M.N., D.M. and A.S. All authors have read and agreed to the published version of the manuscript.

Funding: This study received funding from the Romanian grant PNIII28 PFE BID. Publishing the current paper was financed through Entrepreneurial Education and Professional Counselling for Social and Human Sciences $\mathrm{PhD}$ and Postdoctoral Researchers to ensure knowledge transfer Project; Human Capital Programme (ATRiUM, POCU380/6/13/123343).

Acknowledgments: This paper is dedicated to the memory of our late friend Liviu MĂRUIA, an overenthusiastic field archaeologist who always had spoken highly of Banat's archaeological heritage. Mașloc "Sanțul Turcilor" was a point of reference for many students and archaeology enthusiasts who joined Măruia's fieldwork within the area; some of them co-author the present paper. May he rest in peace! The authors would like to thank Joep Orbons for his valuable and thorough feedback on this paper. Many thanks to Lavinia Nicorescu (archaeology and biology graduate) for helping us identifying the plant growing within the boundaries of the medieval village to be Euphorbia spp. AM -POS Mediu/ANAR, "Proiectul Plan pentru prevenirea, protectia si diminuarea efectelor inundațiilor" provided the LiDAR digital terrain model used in this study for research/non-commercial purposes. It was made available to us through ABA Banat.

Conflicts of Interest: The authors declare no conflict of interest.

\section{References}

1. Agapiou, A. Optimal Spatial Resolution for the Detection and Discrimination of Archaeological Proxies in Areas with Spectral Heterogeneity. Remote Sens. 2020, 12, 136. [CrossRef]

2. Bennett, R.; Welham, K.; Hill, R.A.; Ford, A.L.J. The application of vegetation indices for the prospection of archaeological features in grass-dominated environments. Archaeol. Prospect. 2012, 19, 209-218. [CrossRef]

3. Biagetti, S.; Merlo, S.; Adam, E.; Lobo, A.; Conesa, F.C.; Knight, J.; Bekrani, H.; Crema, E.R.; Alcaina-Mateos, J.; Madella, M. High and Medium Resolution Satellite Imagery to Evaluate Late Holocene Human-Environment Interactions in Arid Lands: A Case Study from the Central Sahara. Remote Sens. 2017, 9, 351. [CrossRef]

4. Calleja, J.F.; Pagés, O.R.; Díaz-Álvarez, N.; Peón, J.; Gutiérrez, N.; Martín-Hernández, E.; Relea, A.C.; Melendi, D.R.; Álvarez, P.F. Detection of buried archaeological remains with the combined use of satellite multispectral data and UAV data. Int. J. Appl. Earth Obs. Geoinf. 2018, 73, 555-573. [CrossRef]

5. Crawford, O.G.S. Archaeology in the Field; Phoenix House: London, UK, 1953.

6. Fowler, M.L. Middle Mississippian agricultural fields. Am. Antiq. 1969, 34, 365-375. [CrossRef]

7. Lasaponara, R.; Masini, N. Detection of archaeological crop marks by using satellite QuickBird multispectral imagery. J. Archaeol. Sci. 2007, 34, 214-221. [CrossRef]

8. Parrington, M. Geophysical and Aerial Prospecting Techniques at Valley Forge National Historical Park, Pennsylvania. J. Field Archaeol. 1979, 6, 193-201.

9. Melillos, G.; Themistocleous, K.; Papadavid, G.; Agapiou, A.; Prodromou, M.; Michaelides, S.; Hadjimitsis, D.G. Integrated use of field spectroscopy and satellite remote sensing for defence and security applications in Cyprus. In Proceedings of the Fourth International Conference on Remote Sensing and Geoinformation of the Environment (RSCy2016); International Society for Optics and Photonics: Bellingham, WA, USA, 2016; Volume 9688, p. 96880F.

10. Poirier, N.; Hautefeuille, F.; Calastrenc, C. L'utilisation des micro-drones pour la prospection archéologique à basse altitude. Rev. Française Photogrammétrie Télédétection 2017, 213, 81-94.

11. Holliday, V.T.; Gartner, W.G. Methods of soil P analysis in archaeology. J. Archaeol. Sci. 2007, 34, $301-333$. [CrossRef]

12. Malhotra, H.; Sharma, S.; Pandey, R. Phosphorus Nutrition: Plant Growth in Response to Deficiency and Excess. In Plant Nutrients and Abiotic Stress Tolerance; Springer: Berlin, Germany, 2018; pp. 171-190.

13. Fernández-Hernandez, J.; González-Aguilera, D.; Rodríguez-Gonzálvez, P.; Mancera-Taboada, J. Image-based modelling from unmanned aerial vehicle (UAV) photogrammetry: An effective, low-cost tool for archaeological applications. Archaeometry 2015, 57, 128-145. [CrossRef]

14. Davis, D.S.; Andriankaja, V.; Carnat, T.L.; Chrisostome, Z.M.; Colombe, C.; Fenomanana, F.; Hubertine, L.; Justome, R.; Lahiniriko, F.; Léonce, H. Satellite-based remote sensing rapidly reveals extensive record of Holocene coastal settlement on Madagascar. J. Archaeol. Sci. 2020, 115, 105097. [CrossRef] 
15. Kirk, S.D.; Thompson, A.E.; Lippitt, C.D. Predictive modeling for site detection using remotely sensed phenological data. Adv. Archaeol. Pr. 2016, 4, 87-101. [CrossRef]

16. Crawford, O.G.S. A Century of Air-photography. Antiquity 1954, 28, 206-210. [CrossRef]

17. Wilson, D.R. Air Photo Interpretation for Archaeologists; 2nd Revised; The History Press Ltd.: Stroud, UK, 2000; ISBN 0752414984.

18. Kobyliński, Ł.M. Klasyfikacja Archeologicznych zdjęć Lotniczych na Podstawie Odkrytej Wiedzy. Ph.D. Thesis, Instytut Informatyki, Warsaw, Poland, February 2005.

19. Pisz, M.; Timoc, C. All roads lead toTibiscum-Results and perspectives of the non-destructive landscape survey of the roman fort and its surroundings. ArheoVest 2015, Nr. III: I, 441-455.

20. Eisenbeiss, H.; Sauerbier, M. Investigation of UAV systems and flight modes for photogrammetric applications. Photogramm. Rec. 2011, 26, 400-421. [CrossRef]

21. Sauerbier, M.; Eisenbeiss, H. Uavs for the Documentation of Archaeological Excavations. In Proceedings of the International Archives of Photogrammetry, Remote Sensing and Spatial Information Sciences, Newcastle, UK, 21-24 June 2010.

22. Verhoeven, G. Taking computer vision aloft-Archaeological three-dimensional reconstructions from aerial photographs with photoscan. Archaeol. Prospect. 2011, 18, 67-73. [CrossRef]

23. Campana, S. Drones in Archaeology. State-of-the-art and Future Perspectives. Archaeol. Prospect. 2017, 24, 275-296. [CrossRef]

24. Hegyi, A.; Urdea, P.; Floca, C.; Ardelean, A.; Onaca, A. Mapping the subsurface structures of a lost medieval village in South-Western Romania by combining conventional geophysical methods. Archaeol. Prospect. 2019, 26, 21-32. [CrossRef]

25. Hegyi, A.; Vernica, M.; Drăguţ, L. An object-based approach to support the automatic delineation of magnetic anomalies. Archaeol. Prospect. 2020, 27, 3-12. [CrossRef]

26. DL 71208 Magyar Nemzeti Levéltár Országos Levéltár (MNL OL) Budapest, HU, Collectio Diplomatica Hungarica/Diplomatikai Levéltár, Diplomatikai leveltár. Available online: https://archives.hungaricana.hu/ en/charters/19941/ (accessed on 15 June 2020).

27. Rationes Collectorum Pontificiorum in Hungaria / Pápai tized-szedők számadásai. 1281-1375; Monumenta Vaticana. Historiam Regni Hungariæ illustrantia / Vatikáni Magy. Okirattár, Ser. Prima. Tomus Primus./Első Sor. Első Kötet., Bp.; 1887; p. 146.

28. Ionaşcu, I.; Lăzărescu-Ionescu, L.; Cîmpina, B.; Stănescu, E.; Prodan, D.; Roller, M. Documente Privind Istoria României. Veacul XIV C Transilvania, Volumul 3; Editura Didactică Şi Pedagogică: Bucuresti, Romania, 1954; Volume 224.

29. Kristó, G. Anjou-kori Oklevéltár /Documenta res Hungaricas Tempore Regum Andegavensium Illustrantia: 1301-1387; Budapest-Szeged; Nemzeti Kulturális Örökség Minisztériuma: Budapest, Hungary, 2000; Volume VI: 1321-1322, ISBN 963482498 6. p. 325 (886).

30. Mályusz, E. Zsigmondkori Oklevéltár: 1387-1399; Akadémiai Kiadó: Budapest, Hungary, 1951; Volume 1, p. 400 (3656).

31. Pesty, F. Krassó vármegye története, Harmadik Kötet. (Oklevéltár. [1230-1518]); Krassó-Szörény Vármegye Közönsége; Az Athenaeum R[észvény]; Társ[ulat]: Budapest, Hungary, 1882; p. 429 (326).

32. DL 93453 (Magyar Nemzeti Levéltár Országos Levéltár (MNL OL) Budapest, HU, Collectio Diplomatica Hungarica / Diplomatikai Levéltár. Available online: https://archives.hungaricana.hu/en/charters/198804/ (accessed on 15 June 2020).

33. Pálffy, G. Egy rendkívüli forrás a magyar politikai elit 16. századi földrajzi ismereteiről. Az 1526 és 1556 között török kézbe került magyarországi városok, várak és kastélyok összeírása a Német-római Birodalom rendjei számára. In Várak Nyomában. Tanulmányok A 60 Éves Feld István Tiszteletére/Auf Den Spuren Der Burgen Jubil. Zum 60. Geburtstag Des Ung. Archaeol. Istvan Fried, Szerk; Terei György—Kovács Gyöngyi-Domokos György—Miklós Zsuzsa-Mordovin Maxim; Castrum Bene Egyesület, Civertan Grafikai Stúdió: Budapest, Hungary, 2011; ISBN 9789630824859, 963082485X. p. 193 (244).

34. Szentkláray, J. Száz év Dél-Magyarország újabb történetéből: 1779-től napjainkig: Tekintettel a II. Károly és Mária Terézia korabeli előményekre; Csanád-Egyház-megyei Könyvnyomda: Temesvár, Timis, 1879; p. 24.

35. Roos, M. Providentia Augustorum: Unter der Obhut der Kaiser: Dokumente zu den Anfängen des Temescher Banats: 1716-1739; Im Selbstverlag des Verfassers sowie im Verlag Musik Südo: Temeswar, Romania, 2018; ISBN 978-3-9390-4127-6. p. 81. 
36. Lipova's district map (1718) (authorless). Mappa \Von dem \Lippovaer und Facseter $\backslash$ District $\backslash$ Worinnen alle bewohnte Dorfschafften, Sambt denen Prædien,\Flussen, Berg und Waldungen enthalten, nach vorgenommener $\backslash$ accurater Geometrischen abmessung Im Jahr 1718 \& 1719. Manuscript map, color copy. Available online: http://maps.hungaricana.hu/hu/47915/ (accessed on 15 June 2020).

37. Timișoara's district map (1720) (authorless). Mappa \Von dem Temesva[r]er. District. $\backslash$ Worinen Alle Bewohnte Dorffschafften, Sambt denen Prædien, Flüssen, bäch, Morasten, und $\backslash$ Waldungen Enthalten, nach Vorgenommener Geometrischer accurater Abmessung $\backslash$ Im Jahr 1720. Manuscript map, color copy. Available online: http: //maps.hungaricana.hu/hu/47936/ (accessed on 15 June 2020).

38. Surdu, B. Aspecte privitoare la situaţia Banatului în 1743. In Anuarul Institutului de Istorie din Cluj; Editura Academiei Române: Bucureşti, Romania; Volume XIII, 1970; pp. 52/46-55/49.

39. Mildenberger, P. Blumenthal im Banat; Heimatortsgemeinschaft Blumenthal; Bader Druck GmbH: Göppingen, Germany, 1990; 352 pg.; p. 68.

40. Vertan, M. Sigilii de Sate, Comune şi târguri din Banatul Istoric (Secolele XVIII-XIX): Catalog; Editura Brumar: Timişoara, Romania, 2006; 92 pg.; ISBN 973-602-194-7, 978-973-602-194-7. p. 56, 86 (383. c).

41. Evans, I.S. General geomorphometry, derivatives of altitude, and descriptive statistics. In Spatial Analysis in Geomorphology; 2019; ISBN 9781000000252. [CrossRef]

42. Franklin, S.E. Geomorphometric processing of digital elevation models. Comput. Geosci. 1987. [CrossRef]

43. Szypuła, B. Digital Elevation Models in Geomorphology. In Hydro-Geomorphology-Models and Trends; Shukla, D.P., Ed.; InTechOpen: London, UK, 2017; pp. 81-112. [CrossRef]

44. De Boer, A.G.; Laan, W.N.H.; Waldus, W.; van Zijverden, W.K. LIDAR-based surface height measurements: Applications in archaeology. Beyond Illus. 2d 3d Digit. Technol. Tools Discov. Archaeol. Br. Arch. Rep. Int. Ser. 2008, 1805, 69-77.

45. Verhagen, P.; Drăguţ, L. Object-based landform delineation and classification from DEMs for archaeological predictive mapping. J. Archaeol. Sci. 2012, 39, 698-703. [CrossRef]

46. Team, P. Planet Application Program Interface: In Space for Life on Earth. San Fr. Ca 2017, 2017, 40.

47. Ghuffar, S. DEM Generation from Multi Satellite PlanetScope Imagery. Remote Sens. 2018, 10, 1462. [CrossRef]

48. Sozzi, M.; Marinello, F.; Pezzuolo, A.; Sartori, L. Benchmark of satellites image services for precision agricultural use. In Proceedings of the AgEng Conference, Wageningen, The Netherlands, 8-12 July 2018; pp. 8-11.

49. Jensen, J.R. Remote Sensing of the Environment: An Earth resource Perspective 2/e; Pearson Education India: Chennai, India, 2009; ISBN 8131716805.

50. Agapiou, A.; Hadjimitsis, D.G.; Alexakis, D.D. Evaluation of broadband and narrowband vegetation indices for the identification of archaeological crop marks. Remote Sens. 2012, 4, 3892-3919. [CrossRef]

51. Mróz, M.; Sobieraj, A. Comparison of several vegetation indices calculated on the basis of a seasonal SPOT XS time series, and their suitability for land cover and agricultural crop identification. Tech. Sci. 2004, 7, 39-66.

52. Silleos, N.G.; Alexandridis, T.K.; Gitas, I.Z.; Perakis, K. Vegetation indices: Advances made in biomass estimation and vegetation monitoring in the last 30 years. Geocarto Int. 2006, 21, 21-28. [CrossRef]

53. Xue, J.; Su, B. Significant remote sensing vegetation indices: A review of developments and applications. J. Sens. 2017, 2017. [CrossRef]

54. Agapiou, A.; Hadjimitsis, D.G. Vegetation indices and field spectroradiometric measurements for validation of buried architectural remains: Verification under area surveyed with geophysical campaigns. J. Appl. Remote Sens. 2011, 5, 53554. [CrossRef]

55. Agapiou, A.; Lysandrou, V.; Lasaponara, R.; Masini, N.; Hadjimitsis, D.G. Study of the variations of archaeological marks at neolithic site of Lucera, Italy using high-resolution multispectral datasets. Remote Sens. 2016, 8, 723. [CrossRef]

56. Agapiou, A.; Lysandrou, V.; Hadjimitsis, D.G. Optical Remote Sensing Potentials for Looting Detection. Geosciences 2017, 7, 98. [CrossRef]

57. Dahiya, S.; Garg, P.K.; Jat, M.K. A comparative study of various pixel-based image fusion techniques as applied to an urban environment. Int. J. Image Data Fusion 2013, 4, 197-213. [CrossRef]

58. Jordan, C.F. Derivation of leaf-area index from quality of light on the forest floor. Ecology 1969, 50, 663-666. [CrossRef] 
59. Rouse, J., Jr.; Haas, R.H.; Schell, J.A.; Deering, D.W. Monitoring Vegetation Systems in the Great Plains with ERTS; NASA: Washington, DC, USA, 1974.

60. Deering, D.W. Measuring" forage production" of grazing units from Landsat MSS data. In Proceedings of the 10th International Symposium of Remote Sensing of the Envrionment, Ann Arbor, MI, USA, 6 October 1975; pp. 1169-1198.

61. Richardson, A.J.; Wiegand, C.L. Distinguishing vegetation from soil background information. Photogramm. Eng. Remote Sens. 1977, 43, 1541-1552.

62. Perry Jr, C.R.; Lautenschlager, L.F. Functional equivalence of spectral vegetation indices. Remote Sens. Environ. 1984, 14, 169-182. [CrossRef]

63. Walther, D.; Shabaani, S. Large Scale Monitoring of Rangelands Vegetation Using NOAA/AVHRR LAC Data: Application to the Rainy Seasons 1989/90 in Northern Kenya. Range Manag. Handb. Kenya 1991, 3, 4.

64. Qi, J.; Chehbouni, A.; Huete, A.R.; Kerr, Y.H.; Sorooshian, S. A modified soil adjusted vegetation index. Remote Sens. Env. 1994, 48, 119-126. [CrossRef]

65. Huete, A.R. A soil-adjusted vegetation index (SAVI). Remote Sens. Environ. 1988, 25, 295-309. [CrossRef]

66. Baret, F.; Guyot, G.; Major, D.J. TSAVI: A vegetation index which minimizes soil brightness effects on LAI and APAR estimation. In Proceedings of the 12th Canadian Symposium on Remote Sensing Geoscience and Remote Sensing Symposium; IEEE: Piscataway, NJ, USA, 1989; Volume 3, pp. 1355-1358.

67. Baret, F.; Guyot, G. Potentials and limits of vegetation indices for LAI and APAR assessment. Remote Sens. Environ. 1991, 35, 161-173. [CrossRef]

68. De Reu, J.; Plets, G.; Verhoeven, G.; De Smedt, P.; Bats, M.; Cherretté, B.; De Maeyer, W.; Deconynck, J.; Herremans, D.; Laloo, P. Towards a three-dimensional cost-effective registration of the archaeological heritage. J. Archaeol. Sci. 2013, 40, 1108-1121. [CrossRef]

69. Măruia, L.; Cîntar, A.; Bolcu, L.; Ardelean, M.; Micle, D.; Stavilă, A.; Borlea, O. ArheoGis: Baza de date a patrimoniului arheologic cuprins în Lista Monumentelor Istorice a judeţului Timiş: Rezultatele cercetărilor de teren; BioFlux: Cluj-Napoca, Romania, 2011; ISBN 978-606-81991-23-2.

70. Condurateanu, B.; Constantinescu, S.; Popescu, I. Digital Atlas of Romania v11.17; Bucharest 2019.

71. Torma, I. Mittelalterliche Ackerfeld-Spuren im Wald von Tamási (Komitat Tolna). Acta Archaeol. Acad. Sci. Hung. 1981, 33, 245-256.

72. Laszlovszky, J. Agriculture in Medieval Hungary. In The Economy of Medieval Hungary; Brill: Leiden, The Netherlands, 2018; pp. 79-112.

73. Horváth, P. Pálóczi Horváth András: Túrkeve története a honfoglalástól a török idők végéig (The History of Túrkeve from the Hungarian Conquest up to the end of the Turkish Period). Túrkeve Földje És Népe 1992, 49-112.

74. Navrátil, V. Povrchový průzkum zaniklé středověké osady Dašovice a její zaniklé plužiny. Hist. Geogr. 1983, 21, 217-233.

75. Nekuda, V. Pfaffenschlag-Zaniklá středověká ves u Slavonic; Blok: Brno, Czech Republic, 1975; p. 277.

76. Buzás, K.; Frigyes, G.; Pánya, I. Középkori templomok nyomában Bács-Kiskun megyében II. VárakKastélyok Templ. 2019, 4, 16-19.

77. Pánya, I. Possibilities and methods for the reconstruction of the settlement structure of medieval Bodrog county. Banatica 2020, 29, 321-358.

78. Pădurean, E.D.; Dorogostaisky, L. Mistere cu privire la imaginea satelitară Google Earth a unui sit arheologic de la Iratoşu, jud. Arad Misteries regarding the Google Earth sattelite image of a archaeological sit from Iratosu, Arad County. An. Aradului 2016, 2, 11-22.

79. Mărginean, F. Contributions to the Medieval Ecclesiastic Geography of Arad County. State of Research. Ziridava. Stud. Archaeol. 2018, 32, 195-220.

80. Engel, P. The Realm of St Stephen, 1st ed.; International Library of Historical Studies, 19, I.B.; Tauris Publishers: London, UK, 2001; ISBN 1860640613.

(C) 2020 by the authors. Licensee MDPI, Basel, Switzerland. This article is an open access article distributed under the terms and conditions of the Creative Commons Attribution (CC BY) license (http://creativecommons.org/licenses/by/4.0/). 